\title{
24. ORGANIC AND CARBONATE CARBON ACCUMULATION ON BROKEN RIDGE AND NINETYEAST RIDGE, CENTRAL INDIAN OCEAN ${ }^{1}$
}

\author{
Ralf Littke, ${ }^{2}$ Jürgen Rullkötter, ${ }^{2}$ and Rainer G. Schaefer ${ }^{2}$
}

\begin{abstract}
Organic petrological and geochemical analyses were performed on samples cored on Broken Ridge and Ninetyeast Ridge in the Central Indian Ocean during Leg 121 . Organic carbon $\left(\mathrm{C}_{\text {org }}\right)$ contents are less than $1 \%$ in each individual sample and average $\mathrm{C}_{\text {org }}$ values calculated for larger stratigraphic units are less than $0.2 \%$. Generally, there is more organic matter in Cretaceous sediments than in Tertiary. In the Cretaceous, the bulk of the organic matter consists of terrigenous debris, but a significant contribution of marine-derived organic matter was found in some samples, especially in the early Maestrichtian on Broken Ridge (Site 754). The youngest Pliocene-Pleistocene sediments at Site 758 (northern part of Ninetyeast Ridge) contain a significant amount of clastic material transported to the site by the (distal) Bengal Fan. In these sediments, $\mathrm{C}_{\text {org }}$ contents of up to $0.9 \%$ were measured and are due to the inflow of terrigenous organic debris. $\mathrm{C}_{\text {org }}$ values are positively correlated with bulk sediment accumulation rates (i.e., sediments contain more organic matter at times of faster deposition). The size of terrigenous organic particles is generally small in all sediments. The extremely small number of particles in the Cretaceous sediments at Site 758 and their smaller grain size, compared to the Cretaceous sediments on Broken Ridge, indicate that Cretaceous surface water paleocurrents flowed from southeast to northwest in the Proto-Indian Ocean.

In the central Indian Ocean, sediments deposited above the carbonate compensation depth consist of nannofossil and foraminiferal oozes. In contrast to $\mathrm{C}_{\text {org }}$ values, calcite contents in the sediments are negatively correlated with bulk sediment accumulation rates (i.e., carbonate oozes were deposited only during times of extremely slow sedimentation). Therefore, older sediments deposited in the young and still narrow Indian Ocean accumulated faster and are less carbonate-rich than Neogene sediments, although carbonate accumulation rates were higher.
\end{abstract}

\section{INTRODUCTION}

The Ninetyeast Ridge is composed of a suite of volcanos extending about $4000 \mathrm{~km}$ in a north-south direction in the central part of the Indian Ocean (Fig. 1). We drilled at Sites 756, 757, and 758 in the southern, central, and northern parts of Ninetyeast Ridge during Leg 121 and recovered basement consisting of basalts as well as overlying pelagic sediments. This volcanic ridge is interpreted as the trace of a hotspot now situated below the Kerguelen-Heard Plateau (see Fig. 1). The ages of the volcanos and oldest sediments of Ninetyeast Ridge vary between about 40 $\mathrm{Ma}$ at Site 756 and about $80 \mathrm{Ma}$ at Site 758 (Peirce et al., 1988, Leg 121 Scientific Party, 1988) and is even older than $80 \mathrm{Ma}$ at Site 211 (von der Borch, Sclater, et al., 1974) and perhaps younger than $40 \mathrm{Ma}$ at Site 254 (Davies, Luyendyk, et al., 1974). Also, the latitude at which sediment deposition took place changed considerably through time, i.e., from $50^{\circ} \mathrm{S}$ for the oldest Cretaceous sediments to $5^{\circ} \mathrm{N}$ for the youngest Quaternary deposits at Site 758 (Figs. 2 and 3; Peirce, Weissel, et al., 1989).

Broken Ridge is an asymmetric carbonate platform in the southern Indian Ocean isolated from continental areas (Fig. 1). It is interpreted as a fragment of a former large volcanic rise of Mesozoic age that was separated from the Kerguelen-Heard Plateau due to rifting in the late Eocene (Peirce et al., 1988, Leg 121 Scientific Party, 1988). Post-rift as well as pre-rift sediments of Santonian to Holocene age (Fig. 4) were penetrated at Sites 752 and 755. About 460 and $190 \mathrm{~m}$ of Upper Cretaceous and Eocene

\footnotetext{
${ }^{1}$ Weissel, J., Peirce, J., Taylor, E., Alt, J., et al., 1991. Proc. ODP, Sci. Results, 121: College Station, TX (Ocean Drilling Program).

${ }^{2}$ Forschungszentrum Jülich GmbH (KFA), Institut für Erdöl und Organische Geochemie, Postfach 19 13, D-5170 Jülich, F.R.G.
}

sediments, respectively, were not recovered during Leg 121 drilling.

It is one of our objectives to document the carbonate carbon and organic carbon flux as a response to changes in paleolatitude and paleotectonic movements. The sediments of Leg 121 are well suited to our goal because the actual water depths, which range from 1000 to $3000 \mathrm{~m}$, are in the same range as water depths through the Cretaceous to Holocene geologic history. There are no indications that extensive shallow-water deposition, subaerial weathering, or sedimentation below the carbonate compensation depth influenced the lithologic composition of the sediments recovered during Leg 121. This is in contrast to sediments in deeper parts of the Indian Ocean which are severely affected by carbonate dissolution as evidenced by the carbonate-poor siliceous oozes and brown clays drilled east of Ninetyeast Ridge, e.g., at DSDP Site $213\left(10^{\circ} \mathrm{S}, 5600 \mathrm{~m}\right.$ water depth; Pimm, 1974). The study of the lithology and major mineralogy of middle Cretaceous to Holocene sediments in the central Indian Ocean may help to improve the understanding of the origin of carbonate-rich deepsea sediments now outcropping on continents at places where the paleotectonic and paleolatitudinal position is even less obvious than in the Indian Ocean.

In addition, we describe the amount and type of organic matter in order to better understand its origin, grain size, and distribution, as well as its diagenetic fate in open-ocean sediments. In a separate contribution, Schaefer et al. (this volume) report on traces of gaseous hydrocarbons in the $\mathrm{C}_{2}-\mathrm{C}_{4}$ range at several sites drilled during Leg 121. Previously, only a limited geochemical data set was published on organic matter in sediments from Ninetyeast Ridge by Hunt (1974: 3 samples from DSDP Site 217) and Simoneit and Burlingame (1974: 4 samples from DSDP Site 217). The only organic petrological study deals with one wood fragment (xylite, vitrinite-precursor) found at the base of the sedimentary sequence of Site 214 (Cook, 1974). 


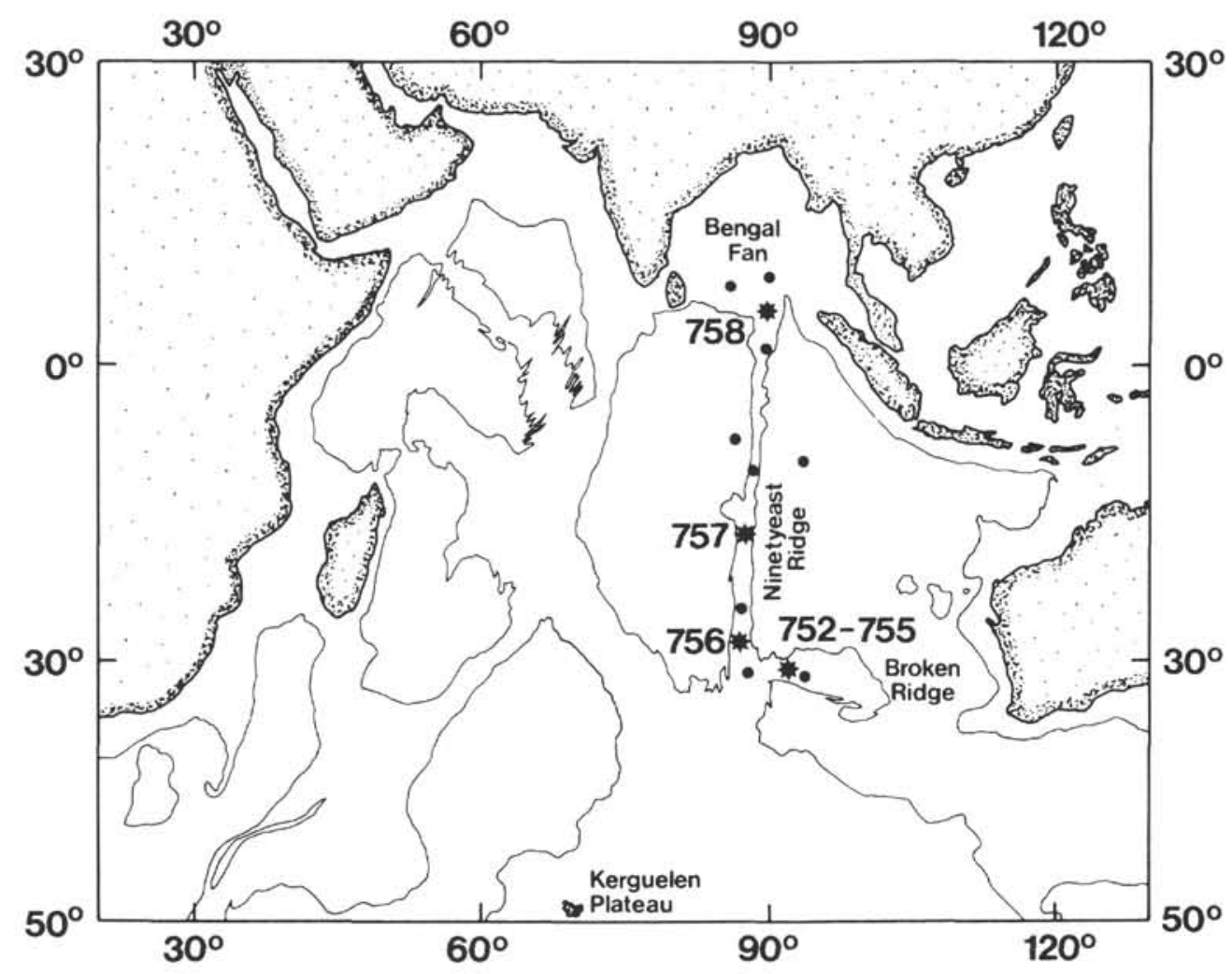

Figure 1. Physiographic features in the Indian Ocean with location of ODP and DSDP sites. The contour line separates regions of more and less than $4000 \mathrm{~m}$ water depth (after Luyendyk and Davies, 1974). Asterisks mark the sites occupied during Leg 121.

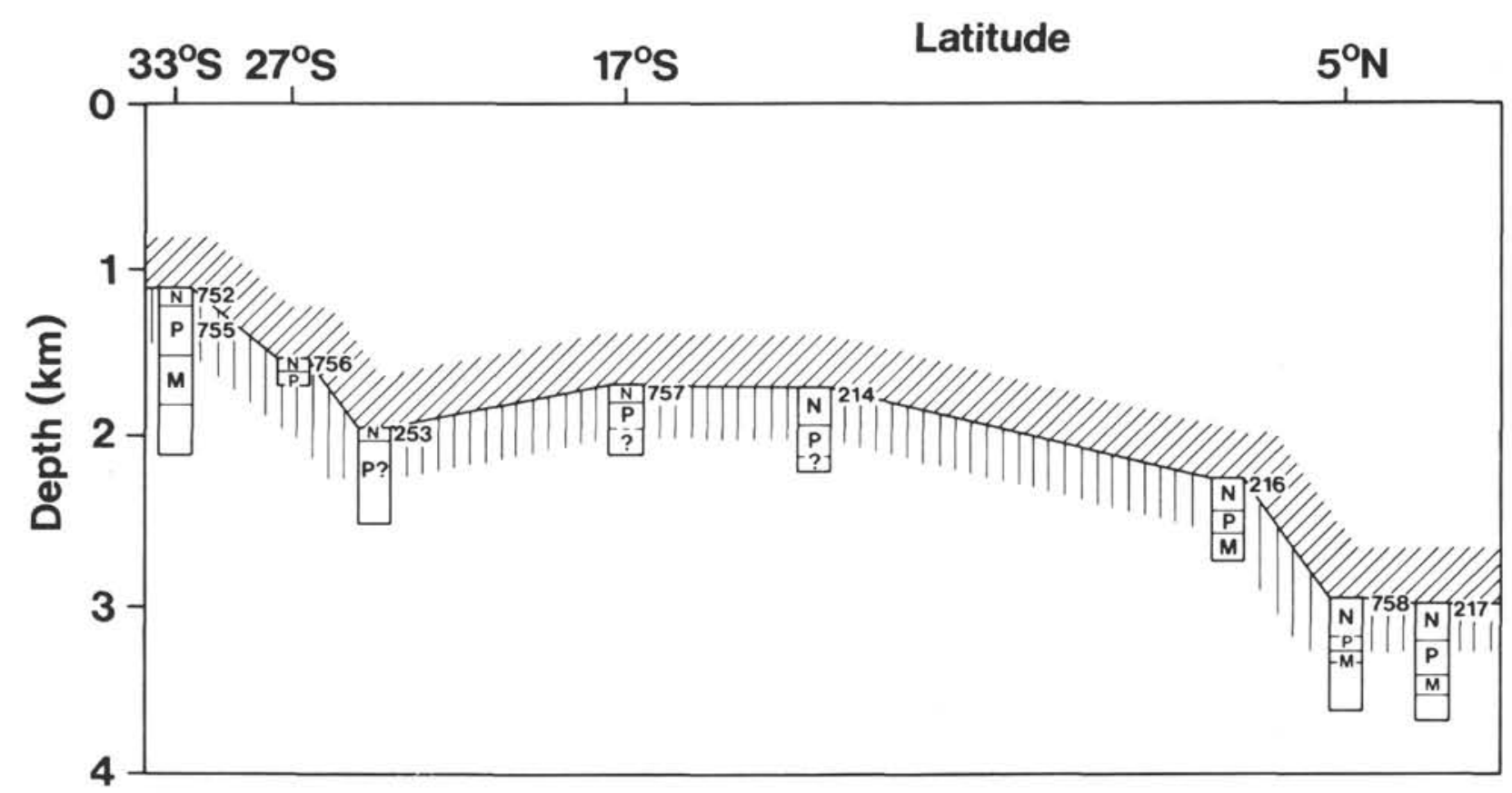

Figure 2. Latitude, water depth, and thickness of major stratigraphic units drilled at DSDP and ODP sites on Ninetyeast Ridge and Broken Ridge. (Note: $\mathrm{N}=$ Neogene, $\mathrm{P}=$ Paleogene, $\mathrm{M}=$ Maestrichtian.) 


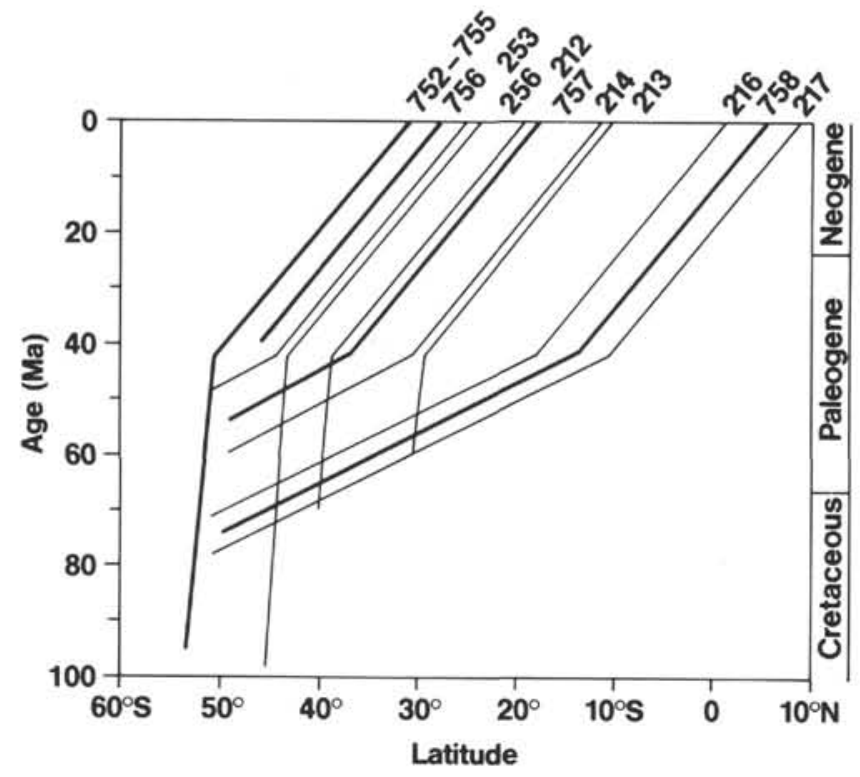

Figure 3. Paleolatitudes of sediments drilled at sites on Broken Ridge (Sites 752-755) and Ninetyeast Ridge (after Peirce, Weissel, et al., 1989).

\section{METHODS}

Total carbon and sulfur concentrations were determined by combustion of dried and ground sediment with a LECO IR-112 analyzer. The same instrument was used for organic carbon $\left(\mathrm{C}_{\text {org }}\right)$ measurements after removal of carbonate with hydrochloric acid. Carbonate carbon contents were calculated by difference. A dif- ferent, coulometric method was used aboard the JOIDES Resolution (Shipboard Scientific Party, 1989). According to Stein et al. (1988), results obtained by these different analytical approaches are almost identical. Therefore, carbonate carbon and $\mathrm{C}_{\text {org }}$ data sets from both methods are combined in this contribution without any numerical correction.

Rock-Eval pyrolysis was performed on a limited amount of samples according to the method described by Espitalié et al. (1977) on a DELSI Rock-Eval II instrument. For this procedure and for solvent extraction only 18 samples with $\mathrm{C}_{\text {org }}>0.1 \%$ were selected. Measurements made aboard the JOIDES Resolution are not repeated here (see Peirce, Weissel, et al., 1989).

Solvent extraction (dichloromethane, $1 \%$ methanol) of 10 samples was carried out by a modified flow-blending technique (Radke et al., 1978). Total extracts were separated into several compound classes by medium pressure liquid chromatography (MPLC; Radke et al., 1980).

Saturated hydrocarbon fractions were analyzed using a VEGA 6180 gas chromatograph (Carlo Erba Strumentazione, Milano) equipped with a fused silica capillary column $(25 \mathrm{~m}$ in length, internal diameter of $0.32 \mathrm{~mm}$ ) coated with cross-linked SE 54 polysiloxane of $0.25-\mu \mathrm{m}$ film thickness. Splitless sample introduction was performed by direct, "on-column" injection of the dissolved samples. The oven temperature was programmed from $60^{\circ} \mathrm{C}$ (hold for $1 \mathrm{~min}$ ) with $30^{\circ} \mathrm{C} / \mathrm{min}$ to $80^{\circ} \mathrm{C}$, then with $4^{\circ} \mathrm{C} / \mathrm{min}$ to $300^{\circ} \mathrm{C}$ (hold for $30 \mathrm{~min}$ ). Helium was used as the carrier gas.

Mass spectrometry studies were performed with a Carlo Erba Fractovap 4160 gas chromatograph, equipped with a fused silica capillary column $(50 \mathrm{~m}$ in length; inner diameter of $0.32 \mathrm{~mm}$ ) coated with Ultra 2 (SE 54 equivalent) and coupled to a VG $7070 \mathrm{E}$ mass spectrometer operating at $70 \mathrm{eV}$. Helium was used as carrier gas, and the temperature programmed from $110^{\circ} \mathrm{C}$ to $300^{\circ} \mathrm{C}$ at $3^{\circ} \mathrm{C} / \mathrm{min}$. Compound identifications are based on comparisons of

\section{LINE 20}

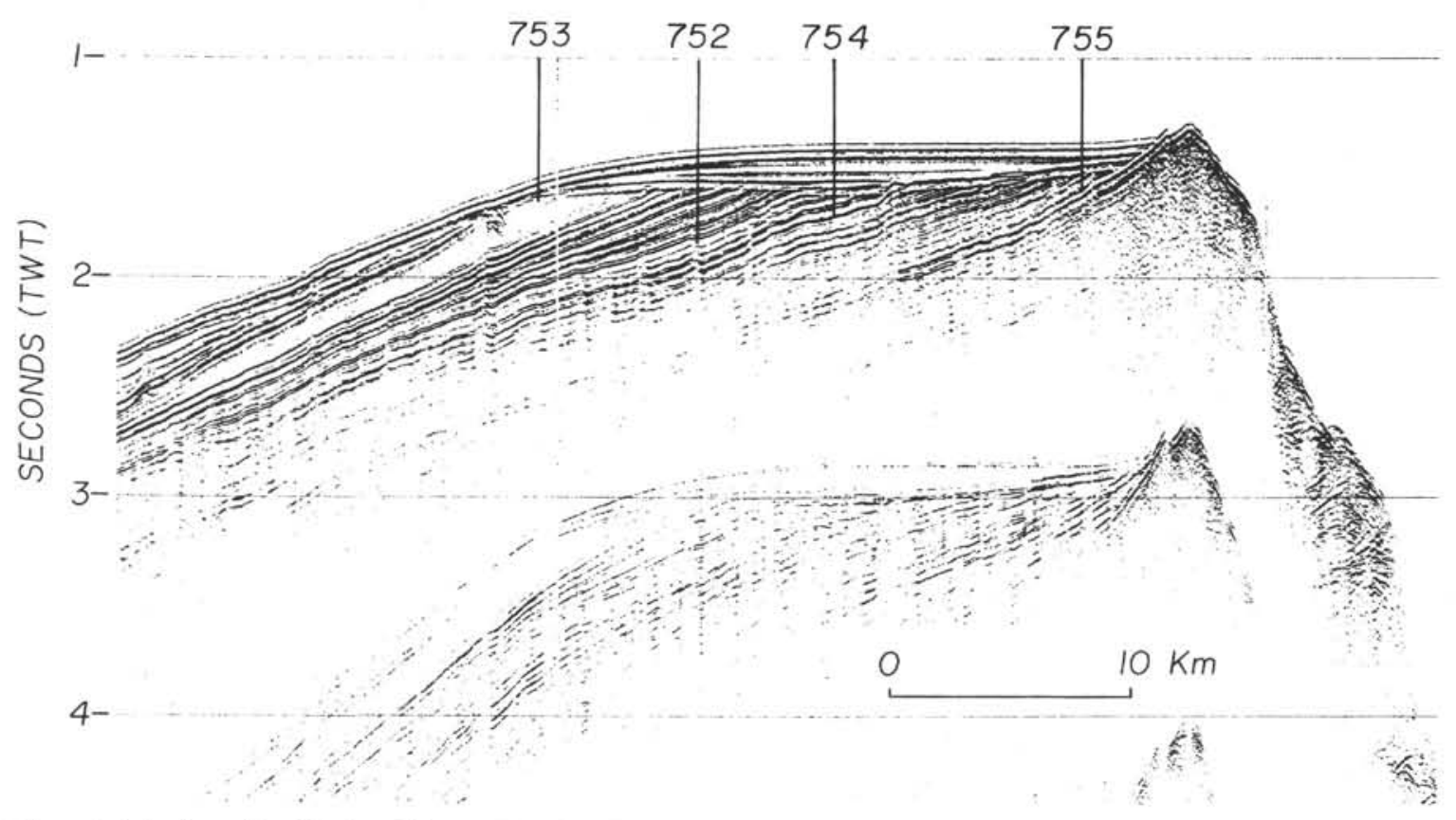

Figure 4. Seismic profile of Broken Ridge and location of Sites 752-755. (Note: TWT = two-way traveltime.) 
relative gas chromatography retention times and mass spectra with those reported in the literature. The distribution of these organic compounds is discussed in qualitative rather than quantitative terms.

Microscopic studies were performed on 5 samples from Hole 754B, 10 samples from Hole 755A, and 4 samples from Hole 758A. Qualitative maceral evaluation was performed by a twoscan method in reflected white light and in a fluorescence mode (Littke et al., 1988).

Accumulation rates (van Andel et al., 1975; Stein et al., 1989b) were calculated for bulk sediment (ARBS), for carbonate (ARC), and for organic carbon (AROC) according to the equation:

$$
\mathrm{AROC}=\left(\mathrm{C}_{\mathrm{org}} / 100\right) \cdot \mathrm{LSR} \cdot(\mathrm{WBD}-1.026 \mathrm{Po} / 100)
$$

where AROC is the mass accumulation rate $\left[\mathrm{g} \cdot \mathrm{cm}^{-2}(1000 \mathrm{a})^{-1}\right], \mathrm{LSR}$ is the linear sedimentation rate $\left[\mathrm{cm} \cdot(1000 \mathrm{a})^{-1}\right]$, WBD is wet-bulk density $\left(\mathrm{g} \cdot \mathrm{cm}^{-3}\right)$, and Po is porosity (\%). LSR, WBD, and Po were calculated according to data in Peirce, Weissel, et al. (1989) for distinct stratigraphic sections.

Surface-water paleoproductivity was estimated using the following empirical equation of Stein et al. (1989b):

$$
P=5.31 \cdot \mathrm{C}_{\mathrm{morg}} \cdot(\mathrm{WBD}-1.026 \cdot \mathrm{Po} / 100)^{0.71} \cdot \mathrm{LSR}^{0.07} \cdot \mathrm{DEP}^{0.45}
$$

where $P$ is paleoproductivity $\left(\mathrm{g} \mathrm{C}_{\mathrm{morg}} \cdot \mathrm{m}^{-2} \cdot \mathrm{a}^{-1}\right), \mathrm{C}_{\text {morg }}$ is marine organic carbon (\%), and DEP is water paleodepth (m). Results can only be regarded as rough estimates because only a very small percentage of marine organic matter is still present in the sediments. The proportion of marine organic carbon was estimated from the microscopical results to be $20 \%$ of the total organic carbon. Based on microscopic observations, a higher proportion (about $40 \%$ ) of marine organic material is only estimated to occur in the Maestrichtian sediments drilled at Site 754 .

\section{RESULTS}

\section{Carbonate Accumulation}

In all cores, calcite is the only or predominant carbonate phase and mainly derived from nannofossils and foraminifers (Peirce, Weissel, et al., 1989). Dolomite only occurs in the oldest sediments recovered at Site 755, but is subordinate in comparison to calcite. Therefore, carbonate carbon percentages were transformed to calcite percentages according to the formula: \% calcite $=8.333 . \%$ inorganic carbon. Calcite contents in samples from Sites 752 and 754-758 are plotted against depth in Figure 5A and against age in Figure 5B. Shipboard data are documented in Peirce, Weissel, et al. (1989).

On Broken Ridge, there is a general increase of carbonate content since sedimentation started $90 \mathrm{Ma}$ ago. In the Santonian section, carbonate contents above carbonate-poor tuffs average $20 \%$ (Site 755, pre-rift sediments). From early to late Maestrichtian, calcite contents increase from $60 \%$ to $70 \%$ (Site 754 , pre-rift sediments) and in the Paleocene and Eocene (Site 752 and 753 , pre-rift sediments), they reach $80 \%$ on average. Neogene post-rift sediments (Sites 752 and 754 ) consistently contain $96 \%$ calcite. Carbonate contents are exceptionally low in a 6-m-thick interval directly above the Cretaceous/Tertiary $(\mathrm{K} / \mathrm{T})$ boundary (Site $752: 18 \% \mathrm{CaCO}_{3}$ ) and at the base of the post-rift sediments in a coarse gravel layer (Sites 752 and 754). Calcite accumulation rates (Table 1) are about $4.3 \mathrm{mg} \cdot \mathrm{cm}^{-2} \cdot \mathrm{a}^{-1}$ in the Maestrichtian, slightly lower in the Paleocene and Eocene $\left(2.5 \mathrm{mg} \mathrm{cm}^{-2} \cdot \mathrm{a}^{-1}\right)$, and much lower above the $\mathrm{K} / \mathrm{T}$ boundary $\left(0.2 \mathrm{mg} \cdot \mathrm{cm}^{-2} \cdot \mathrm{a}^{-1}\right)$ and in the Neogene $\left(0.4 \mathrm{mg} \cdot \mathrm{cm}^{-2} \cdot \mathrm{a}^{-1}\right)$, although sediments in the latter period consist of almost pure carbonate.
At Site 756 on the southern part of Ninetyeast Ridge, carbonate contents in sediments above the basement are generally high and increase from $90 \%$ in the late Eocene to $96 \%$ in the early Miocene. In the overlying strata, there is only one thin "low carbonate" interval in the middle Miocene at $50-55 \mathrm{mbsf}$. Average calcite accumulation rates are about $0.55 \mathrm{mg} \cdot \mathrm{cm}^{-2} \cdot \mathrm{a}^{-1}$ for the Eocene to Oligocene section and only $0.4 \mathrm{mg} \cdot \mathrm{cm}^{-2} \cdot \mathrm{a}^{-1}$ for the Miocene to Holocene sediments. At Site 757 on the central part of Ninetyeast Ridge, pelagic strata of early Eocene to Holocene age overlie a thick sequence of volcanic ash. Carbonate percentages are low in the ash (except for the upper $5 \mathrm{~m}$ ) and consistently at $95 \%$ in the sediments above. Calcite accumulation rates of $0.7 \mathrm{mg}$ $\cdot \mathrm{cm}^{-2} \cdot \mathrm{a}^{-1}$ were calculated for the Eocene and of 0.25 and $0.8 \mathrm{mg}$ $\cdot \mathrm{cm}^{-2} \cdot \mathrm{a}^{-1}$ for the Oligocene to middle Miocene and late Miocene to Holocene sections, respectively.

At Site 758 on the northern part of Ninetyeast Ridge, Campanian to Holocene sediments were recovered, with little or no Eocene sediments present. From the Campanian to late Maestrichtian, carbonate contents increase from $20 \%$ to $80 \%$ and further rise to $95 \%$ in the Paleocene. Above the unconformity, carbonate contents are at $85 \%$ from the Oligocene to the middle Miocene (260-120 mbsf) and continuously decrease to $60 \%$ in the younger sediments. Accumulation rates for calcite are about 2.1 $\mathrm{mg} \cdot \mathrm{cm}^{-2} \cdot \mathrm{a}^{-1}$ for the Campanian, $0.6 \mathrm{mg} \cdot \mathrm{cm}^{-2} \cdot \mathrm{a}^{-1}$ for the Maestrichtian to Paleocene section, $0.4 \mathrm{mg} \cdot \mathrm{cm}^{-2} \cdot \mathrm{a}^{-1}$ for the Oligocene to early Miocene, and $0.8 \mathrm{mg} \cdot \mathrm{cm}^{-2} \cdot \mathrm{a}^{-1}$ for the middle Miocene to Holocene sediments (Table 1).

The carbonate data imply that there is a general increase in carbonate content from the Cretaceous to the Quaternary, but a decrease of carbonate accumulation rates (i.e., a negative correlation) between carbonate content and carbonate accumulation rates (Fig. 6A), as well as between carbonate content and bulk sediment accumulation rates (Fig. 6B).

\section{Organic Carbon Accumulation}

Organic carbon $\left(\mathrm{C}_{\text {org }}\right.$ ) percentages at Sites 752 and 754-758 are plotted in Figure 7. Total organic matter in immature sediments is roughly 1.5 - Corg (Tissot and Welte, 1984). On Broken Ridge, $\mathrm{C}_{\text {org }}$ values are generally smaller than $0.5 \%$. Highest concentrations were recorded in the Santonian section (Site 755), where the average $\mathrm{C}_{\text {org }}$ content is above $0.2 \%$ and a maximum value of $1 \%$ was measured. In the early Maestrichtian, average organic carbon concentrations are almost as "high" as in the Santonian, whereas almost no organic matter occurs in the late Maestrichtian (Sites 754 and 752). In the Paleocene, average $\mathrm{C}_{\text {org }}$ contents again are at about $0.2 \%$. While the pre-rift Eocene and Neogene deposits are almost free of $\mathrm{C}_{\text {org }}$, there is a slight enrichment in the gravel layer at the base of the post-rift sediments (i.e., directly above the Eocene unconformity). Calculated accumulation rates for organic carbon are $6 \mathrm{mg} \cdot \mathrm{cm}^{-2} \cdot \mathrm{a}^{-1} \cdot 1000$ for the Maestrichtian, $5 \mathrm{mg} \cdot \mathrm{cm}^{-2} \cdot \mathrm{a}^{-1} \cdot 1000$ for the Paleocene, $2 \mathrm{mg}$. $\mathrm{cm}^{-2} \cdot \mathrm{a}^{-1} \cdot 1000$ for the Eocene, and less than $1 \mathrm{mg} \cdot \mathrm{cm}^{-2} \cdot \mathrm{a}^{-1}$. 1000 for the Neogene above the gravel layer (Site 754). Higher values of $10 \mathrm{mg} \cdot \mathrm{cm}^{-2} \cdot \mathrm{a}^{-1} \cdot 1000$ were calculated for the Santonian, but the lower degree of stratigraphic resolution within the Cretaceous has to be considered.

On Ninetyeast Ridge, almost no organic carbon was found in sediments at the southern and central Sites 756 and 757, and accumulation rates are lower than $1 \mathrm{mg} \cdot \mathrm{cm}^{-2} \cdot \mathrm{a}^{-1} \cdot 1000$. At Site 758 , average $\mathrm{C}_{\text {org }}$ contents are $0.1 \%$ for the Campanian. Even lower concentrations were recorded for the Maestrichtian to Pleistocene sediments drilled between 30 and 400 mbsf. The highest percentages were found in the youngest sediments which contain up to $0.9 \%$ organic carbon. Calculated organic carbon accumulation rates are $4 \mathrm{mg} \cdot \mathrm{cm}^{-2} \cdot \mathrm{a}^{-1} \cdot 1000$ for the Campanian, less than $1 \mathrm{mg} \cdot \mathrm{cm}^{-2} \cdot \mathrm{a}^{-1} \cdot 1000$ for the Maestrichtian to Paleocene, as 



020406080100020406080100

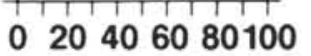
$\mathrm{CaCO}_{3}(\%)$

\section{$\mathrm{CaCO}_{3}(\%)$}
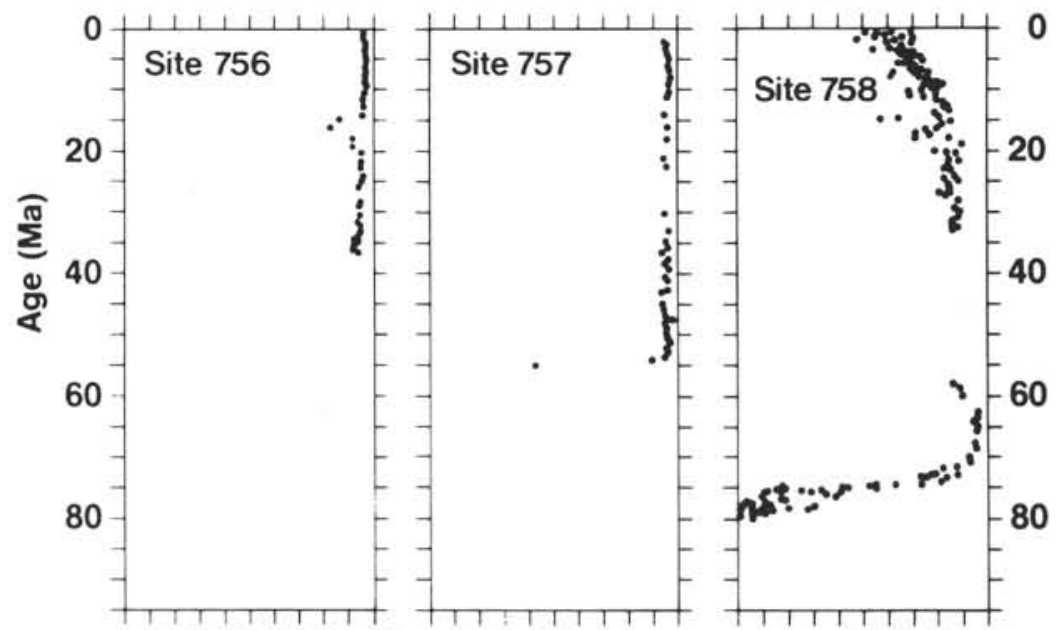

020406080100020406080100020406080100 $\mathrm{CaCO}_{3}(\%)$

$\mathrm{CaCO}_{3}(\%)$

$\mathrm{CaCO}_{3}(\%)$

Figure 5. A. Carbonate content (wt\% of rock) vs. depth for Leg 121 sites. At Site 752, exceptionally low carbonate contents were detected in gravel layers at the Oligocene unconformity (110 mbsf) and above the Cretaceous/Tertiary (K/T) boundary ( 360 mbsf; see Fig. 5B). Extremely low values of only $1 \% \mathrm{CaCO}_{3}$ at Site 754 represent chert layers (170 mbsf). At Site 755 , only a small part of the Neogene ooze section was cored. B. Plots of carbonate content (wt\% of rock) vs. age for different sites. 
Table 1. Average carbonate contents and $\mathrm{C}_{\text {org }}$ percentages, dry-bulk densities, linear sedimentation rates, paleodepths, accumulation rates, and surface water paleo-productivities calculated for various stratigraphic sections drilled on Broken Ridge and Nineyeast Ridge.

\begin{tabular}{|c|c|c|c|c|c|c|c|c|c|}
\hline & $\begin{array}{c}\mathrm{CaCO}_{3} \\
(\%)\end{array}$ & $\begin{array}{l}C_{\text {org }} \\
(\%)\end{array}$ & $\underset{\left(\mathrm{g} / \mathrm{cm}^{3}\right)}{\mathrm{DBD}}$ & $\begin{array}{c}\text { LSR } \\
\left(\mathrm{cm} \cdot(1000 \mathrm{a})^{-1}\right)\end{array}$ & $\begin{array}{l}\text { DEP } \\
(\mathrm{m})\end{array}$ & $\begin{array}{c}\text { ARBS } \\
\left(\mathrm{mg} \cdot \mathrm{cm}^{-2} \cdot \mathrm{a}^{-1}\right)\end{array}$ & $\begin{array}{c}\text { ARC } \\
\left(\mathrm{mg} \cdot \mathrm{cm}^{-2} \cdot \mathrm{a}^{-1}\right)\end{array}$ & $\stackrel{\text { AROC }}{\left(\mathrm{mg} \cdot \mathrm{cm}^{-2} \cdot \mathrm{a}^{-1} \cdot 1000\right)}$ & $\left(\mathrm{g} \cdot \mathrm{m}^{\frac{\mathrm{P}}{2}} \cdot \mathrm{a}^{-1}\right)$ \\
\hline \multicolumn{10}{|l|}{ Sites 752-755 } \\
\hline Oligocene-Holocene & 95 & 0.04 & 1.00 & 0.4 & 1000 & 0.4 & 0.4 & 1 & 4 \\
\hline Eocene & 83 & 0.07 & 1.40 & 2.2 & 1000 & 3.1 & 2.6 & 2 & 8 \\
\hline Paleocene & 67 & 0.13 & 1.50 & 2.5 & 1000 & 3.7 & 2.5 & 5 & 13 \\
\hline Maestrichtian & 65 & 0.10 & 2.00 & 3.3 & 1000 & 6.6 & 4.3 & 6 & 21 \\
\hline Santonian & 16 & 0.21 & 1.90 & 2.5 & 1000 & 4.8 & 0.8 & 10 & 21 \\
\hline \multicolumn{10}{|l|}{ Site 756} \\
\hline Miocene-Holocene & 95 & 0.03 & 1.10 & 0.35 & 1500 & 0.4 & 0.4 & 1 & 4 \\
\hline Eocene-Oligocene & 94 & 0.02 & 1.30 & 0.45 & 1000 & 0.6 & 0.55 & 1 & 3 \\
\hline \multicolumn{10}{|l|}{ Site 757} \\
\hline Lower Miocene-Holocene & 96 & 0.05 & 1.05 & 0.75 & 2000 & 0.8 & 0.8 & 1 & 6 \\
\hline Oligocene-middle Miocene & 95 & 0.05 & 1.25 & 0.2 & 1500 & 0.25 & 0.25 & 1 & 6 \\
\hline Eocene & 95 & 0.03 & 1.55 & 0.45 & 1000 & 0.7 & 0.7 & 1 & 4 \\
\hline \multicolumn{10}{|l|}{ Site 758} \\
\hline Lower Miocene-Holocene & 69 & 0.16 & 0.95 & 1.25 & 3000 & 1.2 & 0.8 & 2 & 17 \\
\hline Oligocene-middle Miocene & 84 & 0.03 & 1.05 & 0.5 & 2500 & 0.5 & 0.45 & 1 & 5 \\
\hline (Maestrichtian)-Paleocene & 92 & 0.02 & 1.35 & 0.5 & 2000 & 0.7 & 0.6 & 1 & 4 \\
\hline${ }^{a}$ Campanian & 49 & 0.09 & 1.45 & 2.7 & 1000 & 3.9 & 1.9 & 4 & 10 \\
\hline
\end{tabular}

Note: $\mathrm{DBD}=$ dry-bulk density $(\mathrm{DBD}=$ wet-bulk density $-1.026(\mathrm{Po} / 100) ; \mathrm{LSR}=$ linear sedimentation rates; $\mathrm{ARBS}=$ bulk sediment accumulation rates; $\mathrm{ARC}=$ carbon accumulation rates; $\mathrm{AROC}=$ organic carbon accumulation rates; $\mathrm{DEP}=$ water paleodepths; and $\mathrm{P}=$ surface-water paleo-productivities for organic carbon.

${ }^{a}$ Without tuff unit between 430 and 530 mbsf.

well as for the Oligocene to early Miocene, and $2 \mathrm{mg} \cdot \mathrm{cm}^{-2} \cdot \mathrm{a}^{-1}$ - 1000 for the middle Miocene to Holocene section. In the uppermost $30 \mathrm{~m}$ of the core, accumulation rates are higher by a factor of 5-10.

In contrast to inorganic (= carbonate) carbon percentages (Figs. 6A, 6B), organic carbon percentages are positively correlated with bulk sediment accumulation rates (Fig. 8A, 8B) as described by Müller and Suess (1979) for a different set of open-marine sediments.

Productivity rates (Table 1) estimated for different stratigraphic units at Broken Ridge and Ninetyeast Ridge are lower by one order of magnitude than those recorded in near-continent sediments (Stein et al., 1989a) and lower by two orders of magnitude than those recorded for upwelling areas (Stein et al., 1989 b). Low productivity rates are supported by generally low contents of opal-A, especially in the nannofossil and foraminifer oozes $(<4 \%)$, which are typical for open-ocean sedimentation on Broken Ridge and Ninetyeast Ridge. In contrast to the accumulation rates, calculated productivity rates depend not only on measured data, but also on an estimation of the degree of degradation (preservation). If the degree of degradation is higher than inherent in the formula used, real productivity rates are higher than calculated values.

\section{Organic Matter Type}

Rock-Eval pyrolysis and incident light microscopy (maceral description) were used to evaluate the type of organic matter according to classification systems based on work by Espitalié et al. (1977) and Stach et al. (1982). During Rock-Eval pyrolysis, only small amounts of hydrocarbons were detected. Highest hydrogen indices $(\mathrm{HI})$ were obtained for the Paleocene sediments at Site 752 on Broken Ridge (Table 2). HI values are lower in the Santonian and early Maestrichtian at Sites 755 and 754 and extremely low in the Neogene sediments at Sites 754 and 752 (see also Peirce, Weissel, et al., 1989). At Site 758, best kerogen qualities were established for the Campanian, where HI values of up to $130 \mathrm{mg}$ hydrocarbons/g $\mathrm{C}_{\text {org }}$ were found.

According to the classification system of Espitalié et al. (1977) and Tissot and Welte (1984), the kerogen at all studied sites is of
Type III (i.e., hydrogen-poor organic matter with a low potential to generate hydrocarbons at increased stages of maturation). Type III kerogen usually derives from terrestrial plants. However, results of Rock-Eval pyrolysis measured on organic-matter-lean sediments have to be regarded as rough estimates due to analytical constraints (Katz, 1983; Peters, 1986). Usually, Rock-Eval measurements on kerogen concentrates from marine sediments reveal higher $\mathrm{HI}$ values than measurements on the entire sediments (e.g., Stein et al., 1988).

Microscopic investigations revealed that the bulk of the organic matter consists of terrigenous particles, mainly inertinites. These high-reflecting, chemically almost inert constituents are interpreted as oxidized remains of the debris of higher plants. Vitrinites are less abundant and interpreted as less oxidized terrigenous particles (e.g., Styan and Bustin, 1983). Random reflectance values $\left(R_{r}\right)$ are plotted in Figure 9 for samples between 298 and 345 mbsf from Site 754 (Maestrichtian), between 67 and 204 mbsf from Site 755 (pre-Maestrichtian), and between 307 and 510 mbsf from Site 758 (Maestrichtian). For all samples containing vitrinite, mean $R_{r}$-values of about $0.2 \%-0.3 \%$ were calculated for these particles. No depth trends could be established for mean $R_{r}$ values at any site. Thus, vitrinite reflectance values indicate an overall low thermal maturity of all sediments drilled at Sites 754, 755 , and 758. Interestingly, the ratio of inertinites over vitrinites (i.e., the ratio of particles with $\mathrm{R}_{\mathrm{r}}$ higher than $0.3 \%$ ) to those with $R_{r}$ lower than $0.3 \%$ (Fig. 9) is extremely high at Site 755, viz., in the oldest, pre-Maestrichtian sediments, and much lower in the Maestrichtian and Campanian sediments of Sites 754 and 758.

The size of the terrigenous vitrinites and inertinites is generally small (Figs. 10 and 11) if compared to organic particles from other ODP sites nearer continents (Stein et al., 1988; ten Haven et al., 1990). The largest particles were found in the sediments drilled in the Santonian at Site 755. Unfortunately, the overall extremely small size of vitrinite particles negatively affects the accuracy of mean $R_{r}$-values as maturity indicators. Therefore, the fluorescence color of liptinites was used as an additional, qualitative maturity parameter. In the studied sequence, liptinites are mainly derived from marine organisms, but also from pollen and spore grains. They are much less abundant than inertinites in most 

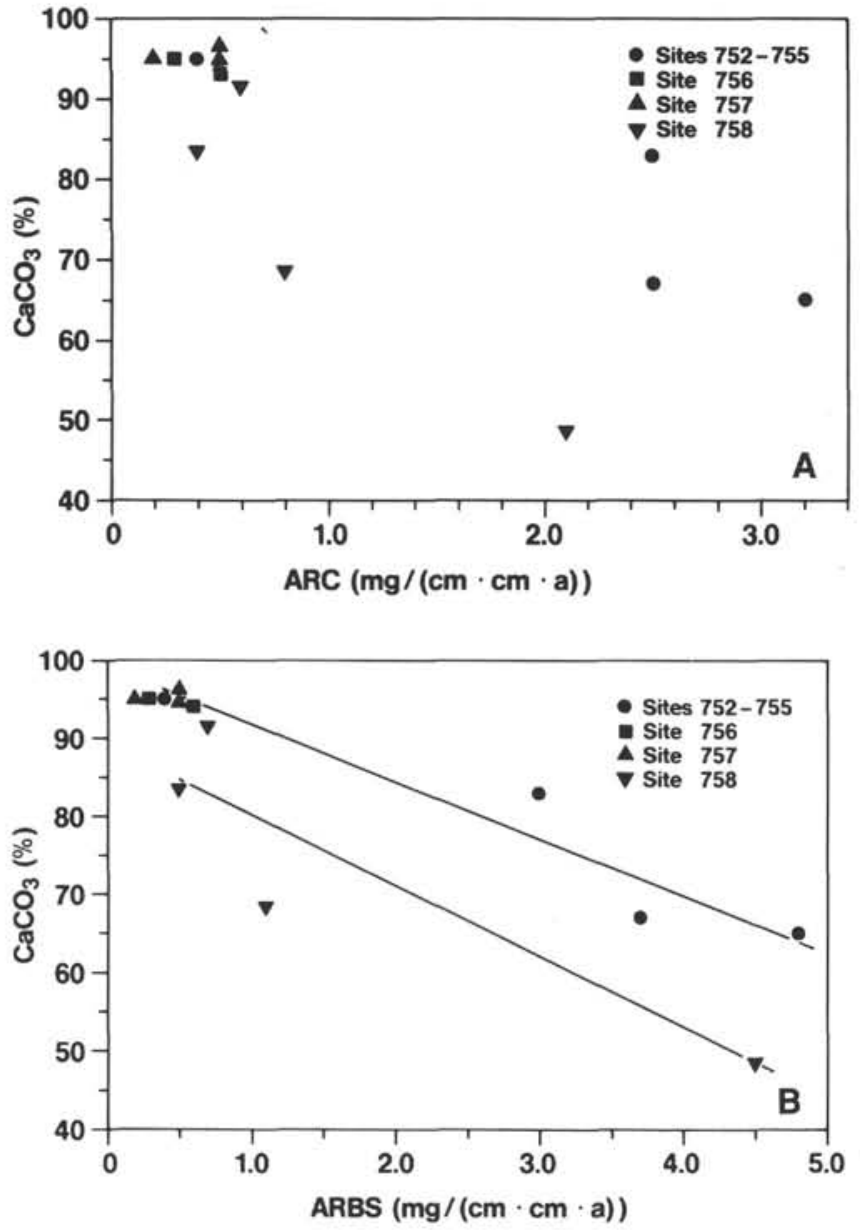

Figure 6. A. Average carbonate content (wt \% of rock) vs. accumulation rates of carbonate (ARC). B. Average carbonate content vs. accumulation rates of bulk sediment (ARBS). Generally, high carbonate percentages are typical for deposition at low rates of both carbonate accumulation and bulk sediment accumulation. The highest accumulation rates for carbonate and bulk sediment, respectively, are probably recorded in the oldest (Santonian) sedimentary units at Broken Ridge, but cannot be quantified due to insufficient stratigraphic resolution. Regression lines were calculated for Broken Ridge Sites 752-755 and for Site 758.

samples. Greatest amounts of liptinites occur in the Maestrichtian sediments of Site 754. The fluorescence of liptinites is bright and green-yellow in all samples investigated. Furthermore, no shift toward lower fluorescence intensities at longer wavelengths was observed with increasing age or depth of the samples, unlike in well-established maturation series at other locations. These data indicate that the stage of thermal hydrocarbon generation (catagenesis, "oil window") was not yet reached (Teichmüller, 1982). In terms of vitrinite reflectance, all samples are well below the $0.5 \%$ $\mathrm{R}_{\mathrm{r}}$ level that often marks the start of hydrocarbon generation from marine organic matter (Leythaeuser, 1975).

\section{Lipid Geochemistry}

In view of the low organic carbon contents of all sediments, only a limited number of samples was selected for chemical analyses of solvent extracts. Extract yields are generally low (less than $12 \mathrm{ppm}$; Table 2) and the saturated hydrocarbon fraction represents only a very small proportion of the total extract. In this respect the molecular data shown below and interpretations derived therefrom should be considered with caution.
Highest yields of soluble organic matter were found in Maestrichtian sediments of Site 754, whereas yields are lower in the Santonian deposits of Site 755 and in the Neogene and Campanian sediments of Site 758 .

Gas chromatograms of the saturated hydrocarbon fraction of a representative sample from each of these sites are presented in Figures $12 \mathrm{~A}-12 \mathrm{C}$. The saturated hydrocarbon fractions of the Maestrichtian sediments from Site 754 (Broken Ridge) are dominated by $n$-alkanes, especially in the $\mathrm{C}_{27}$ to $\mathrm{C}_{35}$ range. The $n$-alkane envelope curves are bimodal due to another maximum around $\mathrm{C}_{15}$ to $\mathrm{C}_{18}$ of varying intensities. Moreover, very longchain $n$-alkanes up to $\mathrm{C}_{44}$ can easily be recognized (Fig. 12A). Much less abundant are steroid hydrocarbons-for example, various diasterenes (see Fig. 13A and Table 3) and isoprenoid hydrocarbons such as pristane and phytane. Concentrations of hopanoid hydrocarbons (Fig. 13A) are very weak in these samples. Among the $n$-alkanes, there is a marked predominance of odd- over even-numbered compounds in the $\mathrm{C}_{27}$ to $\mathrm{C}_{43}$ range. This indicates both a significant terrigenous organic matter contribution and a low maturity of the organic matter. Pristane/phytane concentration ratios vary between 1.5 and 2.0 , pristane $/ n$-heptadecane concentration ratios between 0.7 and 0.8 (see Table 4).

The $n$-alkanes are also the most abundant saturated hydrocarbon group of Santonian sediments from Site 755 (Broken Ridge). All samples of Santonian age have a strongly bimodal $n$-alkane envelope curve with maxima at $\mathrm{C}_{16}$ to $\mathrm{C}_{18}$ and around $\mathrm{C}_{31}$, which indicates both terrestrial and marine (algal) organic matter sources at this site (Fig. 12B). However, next to the isoprenoids pristane and phytane, hopanoid hydrocarbons are quantitatively the most abundant group, whereas there are only very small amounts of steroid hydrocarbons (Fig. 13B). As in the Maestrichtian sediments from Site 754 there is a marked, yet somewhat less pronounced, predominance of odd-over even-numbered $n$-alkanes in the higher molecular weight range. Pristane/phytane and pristane/ $n$-heptadecane concentration ratios are similar to those mentioned above for the Maestrichtian.

In the sample of Campanian age from Site 758 (Ninetyeast Ridge) short-chain $n$-alkanes $\left(\mathrm{C}_{15}\right.$ to $\left.\mathrm{C}_{18}\right)$ predominate long-chain $n$-alkanes ( $C_{27}$ to $C_{31}$; see Fig. 12C). This may be due to a higher relative proportion of algal organic matter in this sediment compared to the Maestrichtian and Santonian samples from Sites 754 and 755, respectively. The predominance of odd- over even-numbered $n$-alkanes in the $\mathrm{C}_{27}$ to $\mathrm{C}_{31}$ range is again very high (carbon preference index, or CPI $=2.8$ ) which is in accordance with the low maturity of the organic matter. The major difference to the other samples of the Broken Ridge sites is the fact that steroid as well as hopanoid hydrocarbons are present in significant concentrations and that 4-methylsteroids occur (Fig. 13C) which are indicative of dinoflagellates (Robinson et al., 1984). The Neogene sediments from this site contain almost exclusively normal and branched alkanes, but no steroid and hopanoid hydrocarbons. CPI values and isoprenoid hydrocarbon concentration ratios are very similar in all samples of Site 758 (see Table 4).

\section{DISCUSSION}

\section{Carbonate Sedimentation}

Carbonate contents mainly reflect the accumulation of planktonic and benthic fossils through time, although some diagenetically formed carbonates occur (e.g., the Santonian dolomites). The rate of carbonate accumulation is affected by the structural position and the climatic and oceanographic conditions at a given time. In the case of the Leg 121 sediments, it is not affected by carbonate dissolution in deep water beneath the carbonate compensation depth (see Kennett, 1982). 

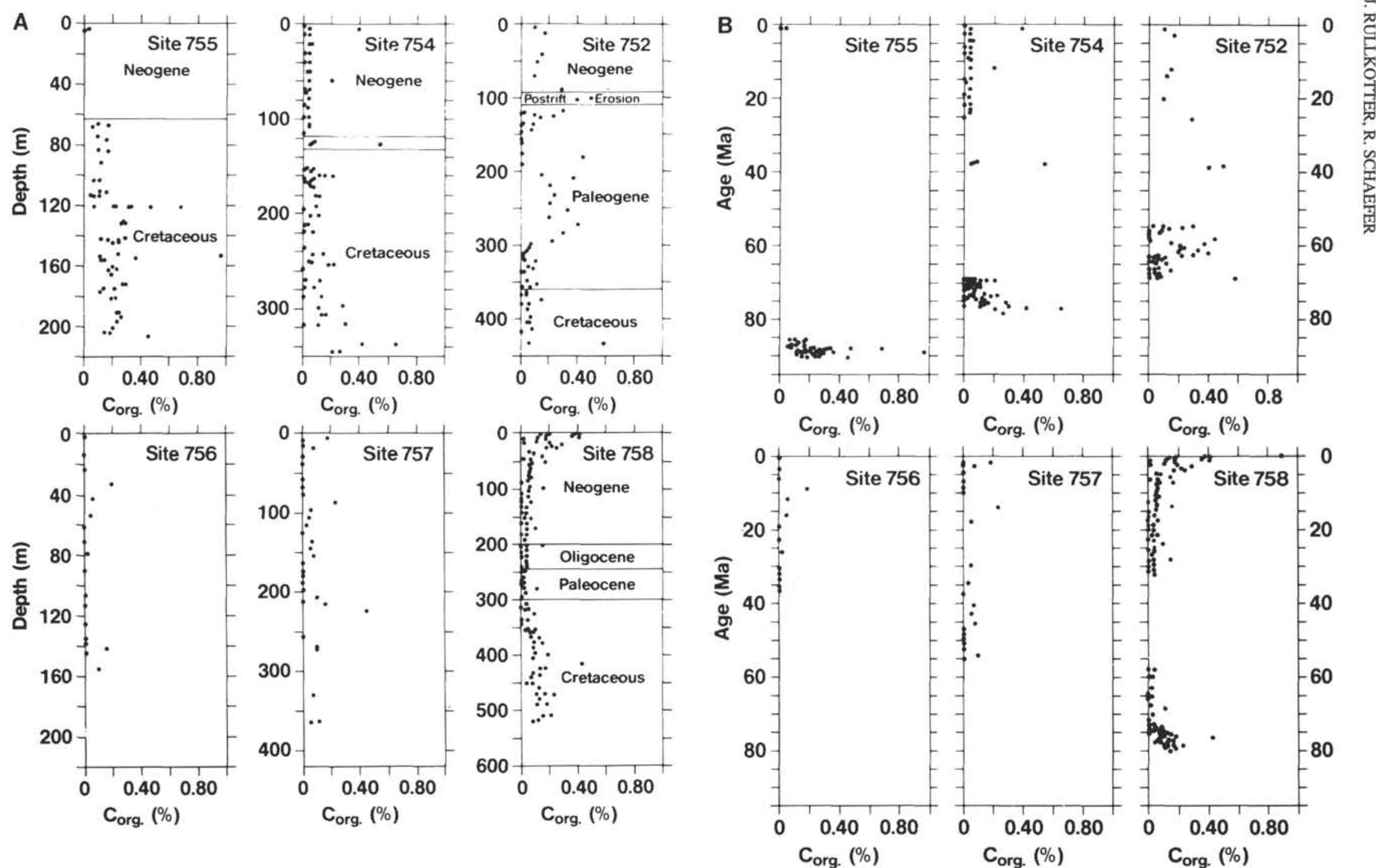

Figure 7. A. Organic carbon content (wt\% of rock) vs. depth for Leg 121 sites. B. Organic carbon content (wt\% of rock) vs. age for Leg 121 sites. 

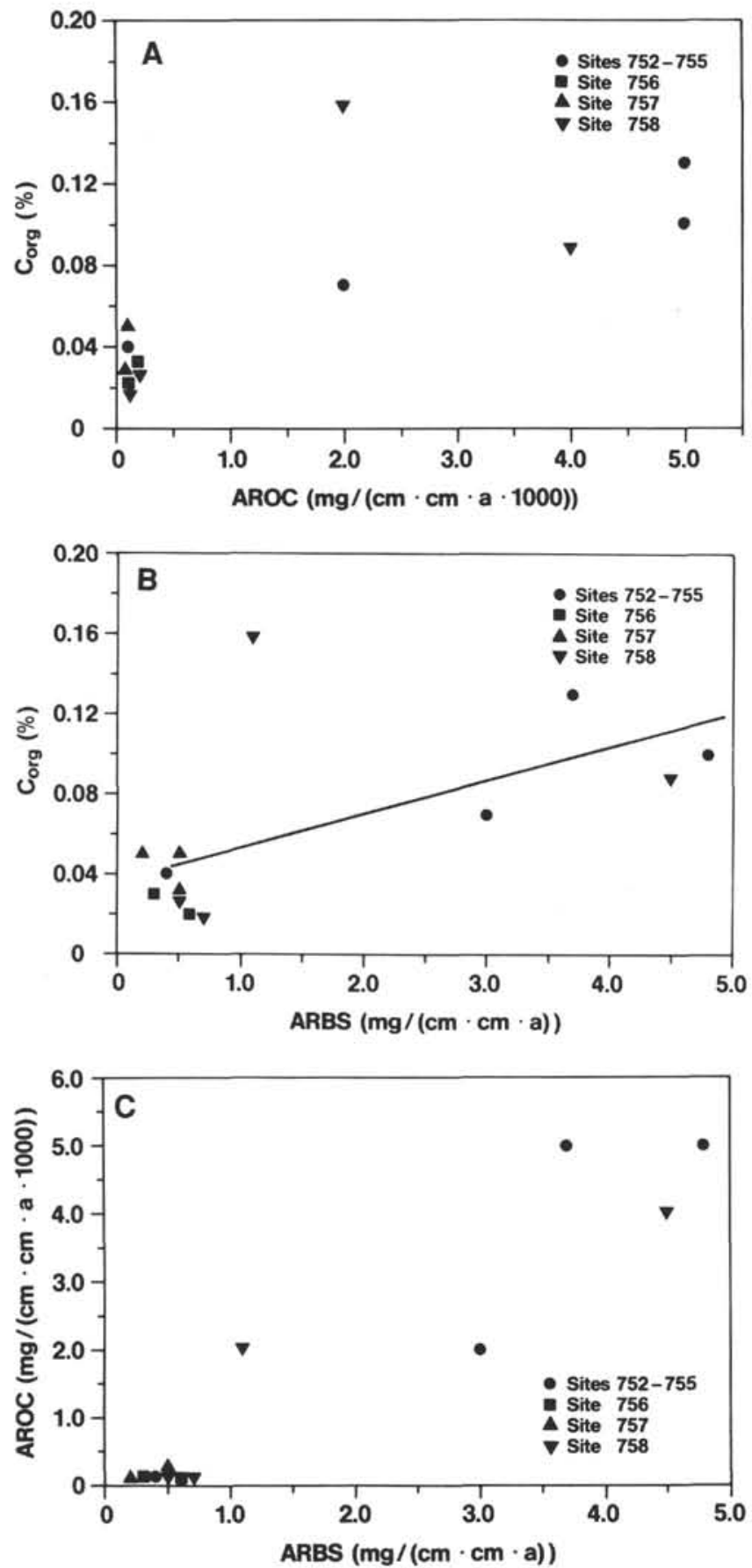

Figure 8. A. Average organic carbon content (wt $\%$ of rock) vs. accumulation rates for organic carbon (AROC). B. Average organic carbon content vs. accumulation rates for bulk sediment (ARBS). Generally, high organic carbon contents coincide with high accumulation rates both of bulk sediment and organic carbon. Highest accumulation rates of organic carbon are probably recorded in the oldest (Santonian) sedimentary units at Broken Ridge (see Figs. $7 \mathrm{~A}$ and $7 \mathrm{~B}$ ), but cannot be quantified due to insufficient stratigraphic resolution. A regression line was calculated for Broken Ridge Sites 752-755. C. Plot of organic carbon accumulation rates vs. bulk sediment accumulation rates. Note the exponential type of correlation between both parameters.
On Broken Ridge, the oldest, carbonate-poor pyroclastic rocks of Santonian and older age correspond to a phase when Broken Ridge was still part of the Kerguelen-Heard Plateau, and when the Indian Ocean was still rather narrow (von der Borch, Sclater, et al., 1974). At this time, great amounts of volcanic ash were produced in the vicinity of the sampling sites. The difference between the low carbonate contents in the lower $50 \mathrm{~m}$ of the Santonian section and the higher values in the upper $100 \mathrm{~m}$ reflects a major and sudden decrease in the volcanic activity and thus a decreasing dilution of carbonate with volcanic ash. This may be related to the separation between India and Kerguelen along a north-south-directed spreading center that started about 80 m.y. ago (Royer and Sandwell, 1989). Nutrients were provided to the Santonian sea, together with the volcanic material, which led to a relatively high surface-water bioproductivity. This is expressed in higher carbonate accumulation rates and organic carbon accumulation rates in the oldest (carbonate-poor) units on Broken Ridge compared to all younger units (Table 1, Figs. 6 and 8).

An evolution toward higher carbonate percentages is recorded in the Maestrichtian-Eocene limestones, chalks, and oozes of Sites 754, 752, and 753 (Figs. 5 and 6). This evolution reflects the continuing opening of the Indian Ocean (Royer and Sandwell, 1989) with a diminished supply of volcanic material at a fairly uniform carbonate accumulation rate (Table 1). The high-latitude position also favored the bioproduction of silica which is an abundant constituent in the Maestrichtian to Paleocene deposits. Much higher carbonate contents but much lower sediment accumulation rates characterize the Neogene open-ocean sedimentation on Broken Ridge. The predominance of carbonate is explained by the spreading of Broken Ridge toward lower latitudes with warmer climate, in which carbonate-producing plankton is often predominant, especially at low rates of bioproductivity (Calvert, 1974; Füchtbauer, 1988, p. 234 and 510). The overall low accumulation rates for all biogenic compounds such as silica and calcite seem to correspond to a drastic decrease in fertility from the pre-rift toward the post-rift situation. This probably reflects the great influence of the Kerguelen-Heard Plateau on nutrient supply during pre-rift sedimentation on Broken Ridge.

The drastic decrease in carbonate content $(18 \%)$ and carbonate accumulation rate above the $\mathrm{K} / \mathrm{T}$ boundary reflects a decrease in carbonate biosynthesis or increase in carbonate dissolution by a factor of 10 . On the other hand, a relatively high amount of biogenic opal-A (probably $>10 \%$ ) found in one sample from this interval by X-ray diffraction analysis aboard the JOIDES Resolution seems to indicate that silica bioproduction was less affected than production of carbonate shells. Possible explanations for this observation include (1) a cooling of seawater favoring silica rather than carbonate bioproduction; (2) an increase in $\mathrm{CO}_{2}$-concentration in the seawater leading to a shallower carbonate compensation depth, or (3) a generally greater resistivity of silicaforming organisms to the environmental changes affecting the sea at that time.

Sediments at Sites 756 and 757 on Ninetyeast Ridge are as carbonate-rich as Neogene sediments on Broken Ridge (Fig. 5) and are also regarded as deposits of a (warm) open ocean. However, carbonate sedimentation started much earlier than on Broken Ridge, i.e., in the late Eocene (Site 756) or early Eocene (Site 757). Low accumulation rates of calcite or bulk sediment demonstrate the similarity between Neogene on Broken Ridge and the Eocene to Holocene section on the southern and central parts of Ninetyeast Ridge caused by sedimentation below open-ocean waters in which low productivity prevailed. The slightly lower carbonate content in the middle Miocene at Site 756 coincides with well known atmospheric and hydrospheric global cooling accompanying the formation of major Antarctic ice caps (Kennett 
Table 2. Hydrogen index values and soluble organic matter in selected samples from Sites 754, 755 (Broken Ridge), and 758 (Ninetyeast Ridge).

\begin{tabular}{|c|c|c|c|c|c|}
\hline Sample & $\begin{array}{l}\text { Depth } \\
\text { (mbsf) }\end{array}$ & $\begin{array}{l}\mathrm{C}_{\text {org }} \\
(\%)\end{array}$ & $\begin{array}{c}\mathrm{CaCO}_{3} \\
(\%)\end{array}$ & $\begin{array}{c}\text { Hydrogen } \\
\text { index } \\
\left.\text { (mg/g C }{ }_{\text {org }}\right)\end{array}$ & $\begin{array}{c}\text { Soluble } \\
\text { organic } \\
\text { matter } \\
\text { (mg/g C }{ }_{\text {org }} \text { ) }\end{array}$ \\
\hline 121-754B-15R-5, 38-41 & 254.58 & 0.12 & 50.7 & 33 & 7.5 \\
\hline 121-754B-24R-2, 24-29 & 337.05 & 0.65 & 69.4 & 146 & 1.8 \\
\hline 121-754B-25R-1, 44-46 & 345.44 & 0.26 & 65.3 & 50 & 4.2 \\
\hline $121-755 \mathrm{~A}-5 \mathrm{R}-2,83-86$ & 67.53 & 0.17 & 18.9 & 24 & - \\
\hline 121-755A-7R-2, 16-19 & 83.46 & 0.10 & 19.3 & 12 & - \\
\hline $121-755 \mathrm{~A}-11 \mathrm{R}-1,21-24$ & 120.93 & 0.21 & 5.2 & 19 & 3.8 \\
\hline $121-755 \mathrm{~A}-12 \mathrm{R}-1,85-88$ & 131.97 & 0.26 & 8.1 & 31 & - \\
\hline $121-755 \mathrm{~A}-13 \mathrm{R}-1,93-96$ & 141.67 & 0.29 & 36.5 & 28 & 2.4 \\
\hline $121-755 \mathrm{~A}-14 \mathrm{R}-4,12-15$ & 154.95 & 0.36 & 37.9 & 25 & 1.7 \\
\hline $121-755 \mathrm{~A}-15 \mathrm{R}-2,62-65$ & 162.12 & 0.23 & 8.7 & 22 & - \\
\hline $121-755 \mathrm{~A}-16 \mathrm{R}-2,96-98$ & 172.10 & 0.27 & 4.6 & 15 & 1.9 \\
\hline $121-755 \mathrm{~A}-18 \mathrm{R}-2,108-110$ & 190.70 & 0.23 & 22.2 & 30 & - \\
\hline $121-755 \mathrm{~A}-19 \mathrm{R}-4,63-66$ & 204.29 & 0.18 & 0.6 & 28 & 2.2 \\
\hline $121-758 \mathrm{~A}-1 \mathrm{H}-2,105-108$ & 2.55 & 0.20 & 61.1 & 45 & 3.5 \\
\hline $121-758 \mathrm{~A}-3 \mathrm{H}-2,95-98$ & 18.05 & 0.20 & 64.9 & 35 & 2.5 \\
\hline $121-758 \mathrm{~A}-4 \mathrm{H}-2,95-98$ & 27.65 & 0.18 & 65.4 & 39 & - \\
\hline $121-758 \mathrm{~A}-56 \mathrm{R}-2,80-83$ & 510.70 & 0.21 & 11.9 & 33 & 1.9 \\
\hline $121-758 \mathrm{~A}-57 \mathrm{R}-1,91-94$ & 518.81 & 0.12 & 19.7 & 50 & - \\
\hline
\end{tabular}

Note: Dash $=$ not measured.
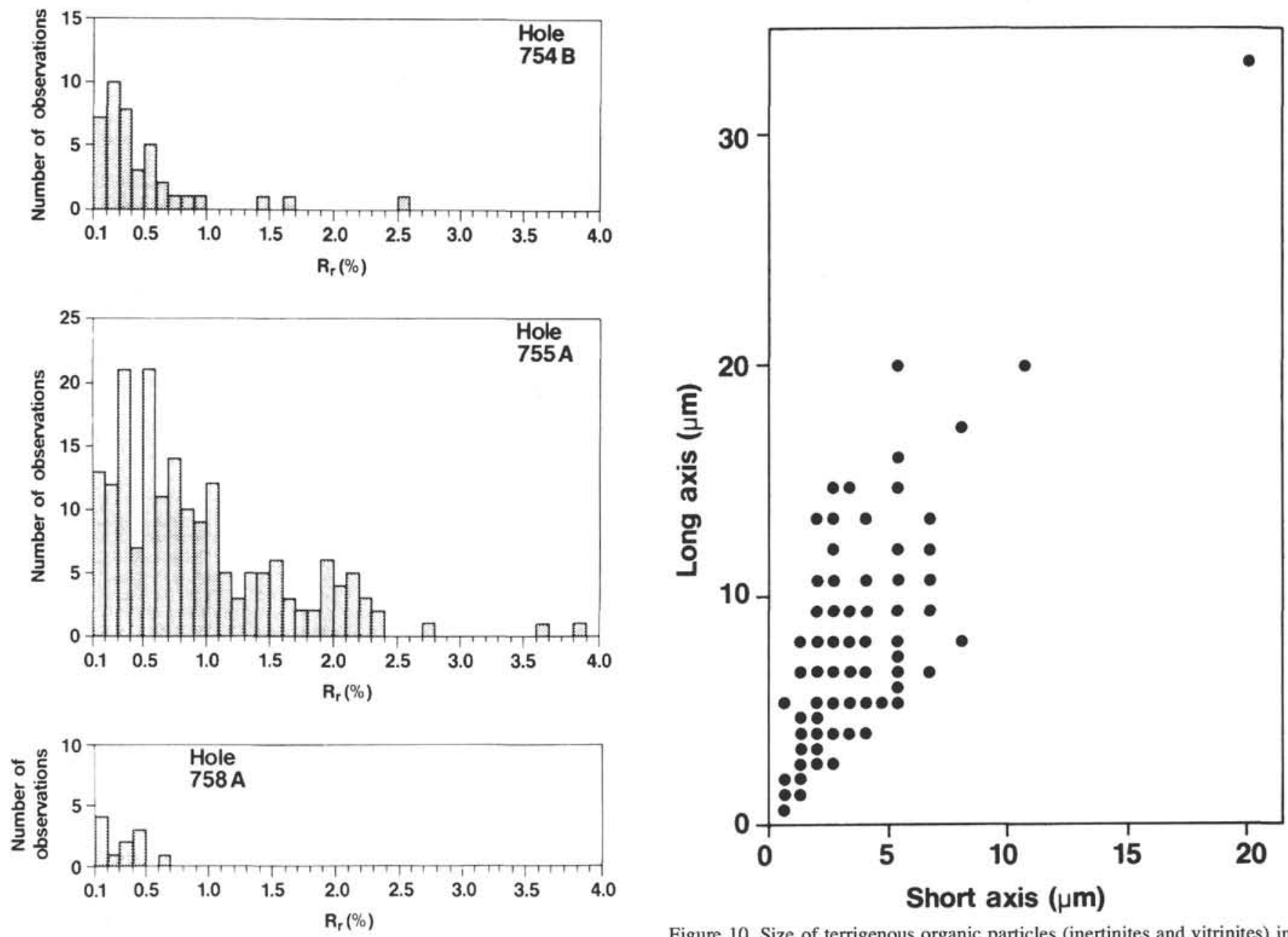

Figure 10. Size of terrigenous organic particles (inertinites and vitrinites) in

Figure 9. Histograms of random reflectance values $\left(R_{r}\right)$ of vitrinites $(<0.3 \%)$ and inertinites in sediments from Sites 754, 755, and 758. samples from Sites 754, 755, and 758. Particles of more than $15-\mu \mathrm{m}$ length and more than $10-\mu \mathrm{m}$ width are rare. 

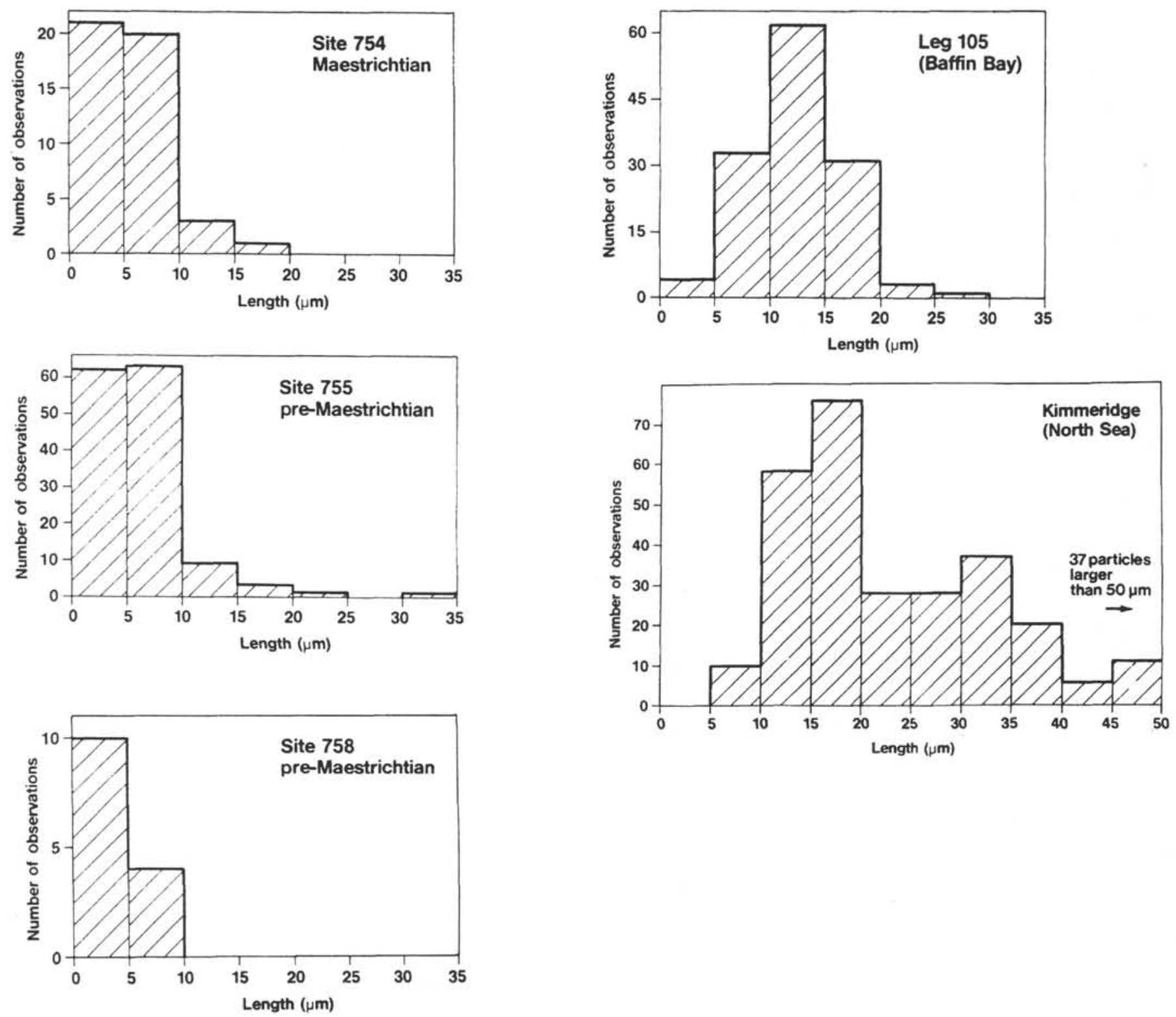

Figure 11. Histograms of length of organic particles at Sites 754, 755, and 758, and, for comparison, at Site 645 (Leg 105) situated between Greenland and Baffin Bay (i.e., near land; see Stein et al., 1989) and the Kimmeridge Clay in the North Sea (see Leythaeuser et al., 1988).

et al., 1975) and the first glacial deposits in the Arctic region (e.g., Denton and Armstrong, 1969).

At Site 758 on the northern part of Ninetyeast Ridge, only the Paleocene section between 250 and 293 mbsf shows the aforementioned character of tropical open-ocean deposits without much continental influence (i.e., high carbonate percentages with an average of $95 \%$ and low accumulation rates). In the underlying Maestrichtian to Campanian sediments, carbonate percentages increase from $15 \%$ to $95 \%$, reflecting higher supply of silica and volcanic ash in the older sediments. This is interpreted as a response to the then still-narrow Indian Ocean, in which sources for volcanic input were close to the young Ninetyeast Ridge. The fact that the ash contents in the upper Maestrichtian to Paleocene section on Broken Ridge are higher than those in equivalent deposits at Site 758 leads to the suggestion that the source for the ashes was closer to Broken Ridge than to Ninetyeast Ridge or more directly downwind (Dehn et al., this volume). The high content of biogenic silica in the Cretaceous at Site 758 and its much lower abundance $(<4 \%)$ in the Paleocene section (which is rich in biogenic silica on Broken Ridge) seems to reflect the rapid northward movement of Site 758 (Calvert, 1974). The Cretaceous silica deposition indicates deposition under nutrient-enriched water with increased bioproductivity (Table 1; see Mienert et al., 1989). The Neogene sediments at Site 758 nicely reflect the collision of India and Asia by the increasing deposition of fluvial clay minerals. The steady increase of terrestrial sedimentation over the last $12 \mathrm{Ma}$ in this distal and elevated part of the Bengal Fan seems to be related to the ongoing uplift of the Himalayan mountains. This sedimentary sequence is discussed in detail by Farrell and Janecek (this volume).

\section{Organic Matter Accumulation}

Preservation of organic matter in deep-sea sediments is much less favored in the open ocean than close to continental margins. Deposition in the open ocean in addition to a reduction of the overall accumulation rate is accompanied by strong fractionation 


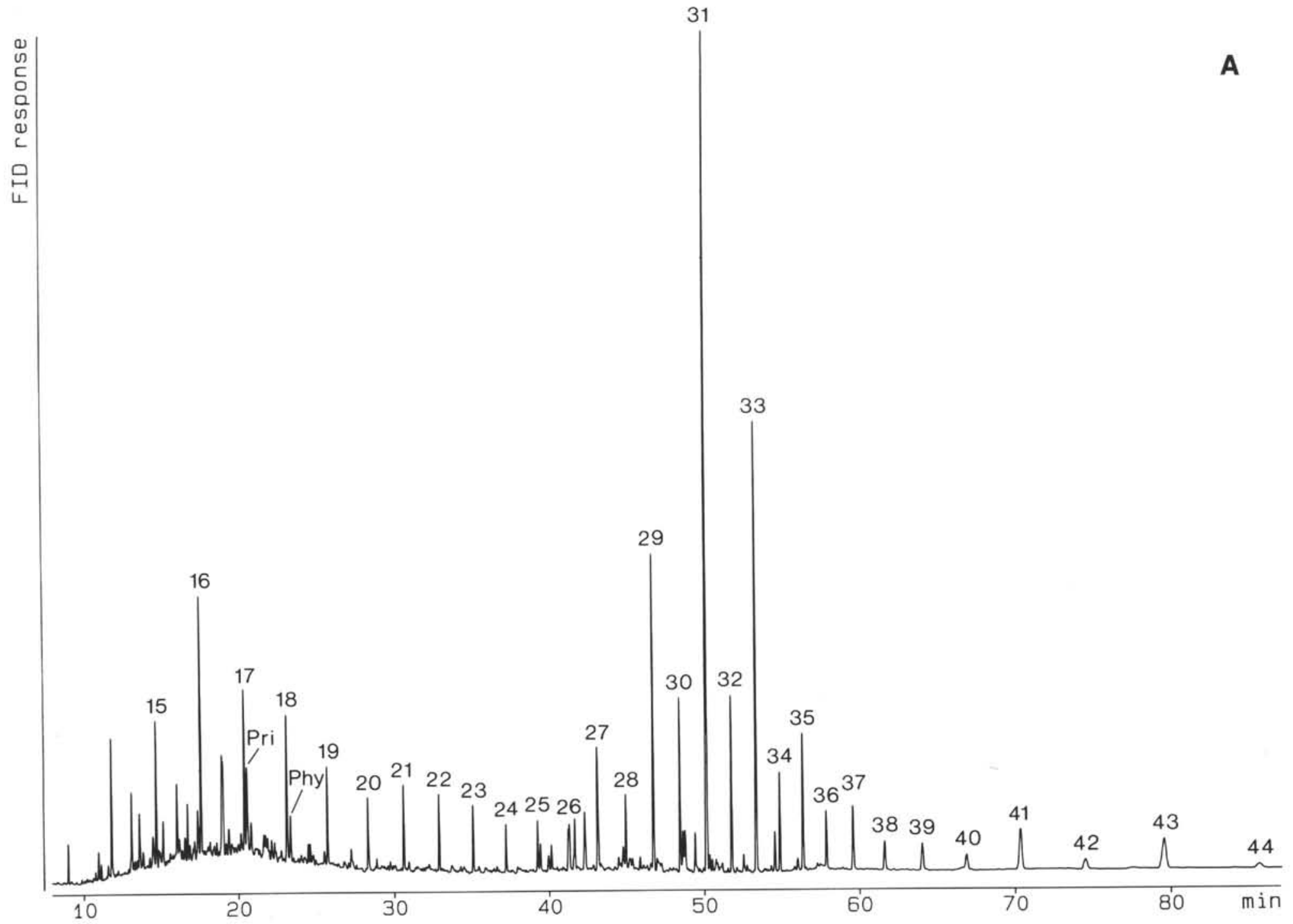




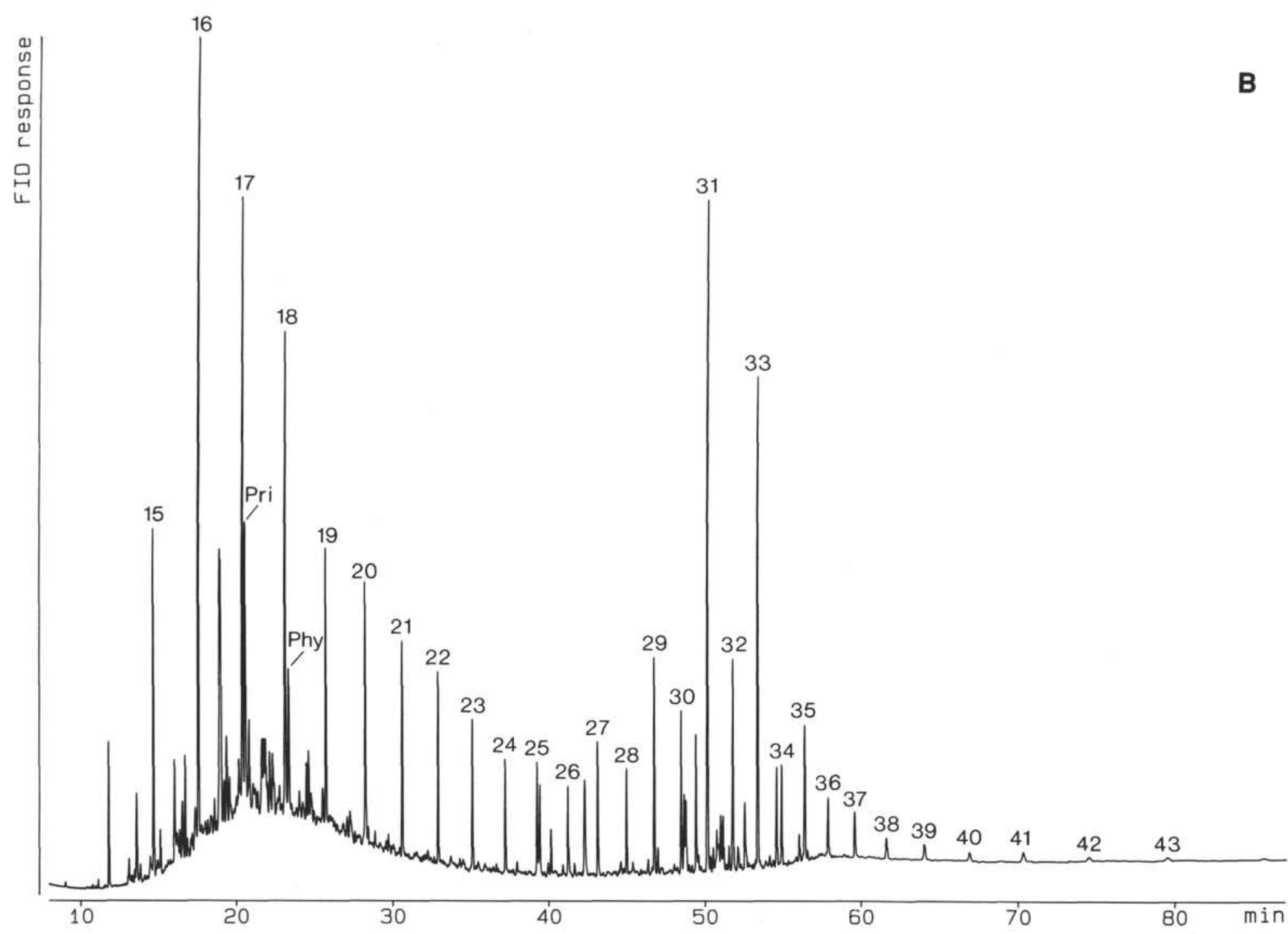

Figure 12. Capillary gas chromatograms of the saturated hydrocarbon fraction of selected samples from Sites 754, 755, and 758. A. Sample 121-754B-24R-2, 24-29 cm (337.05 mbsf). B. Sample 121-755A-14R-4, 12-15 cm (154.95 mbsf). C. Sample 121-758A-56R-2, 80-83 cm (510.70 mbsf). (Note: FID = flame ionization detector.) 


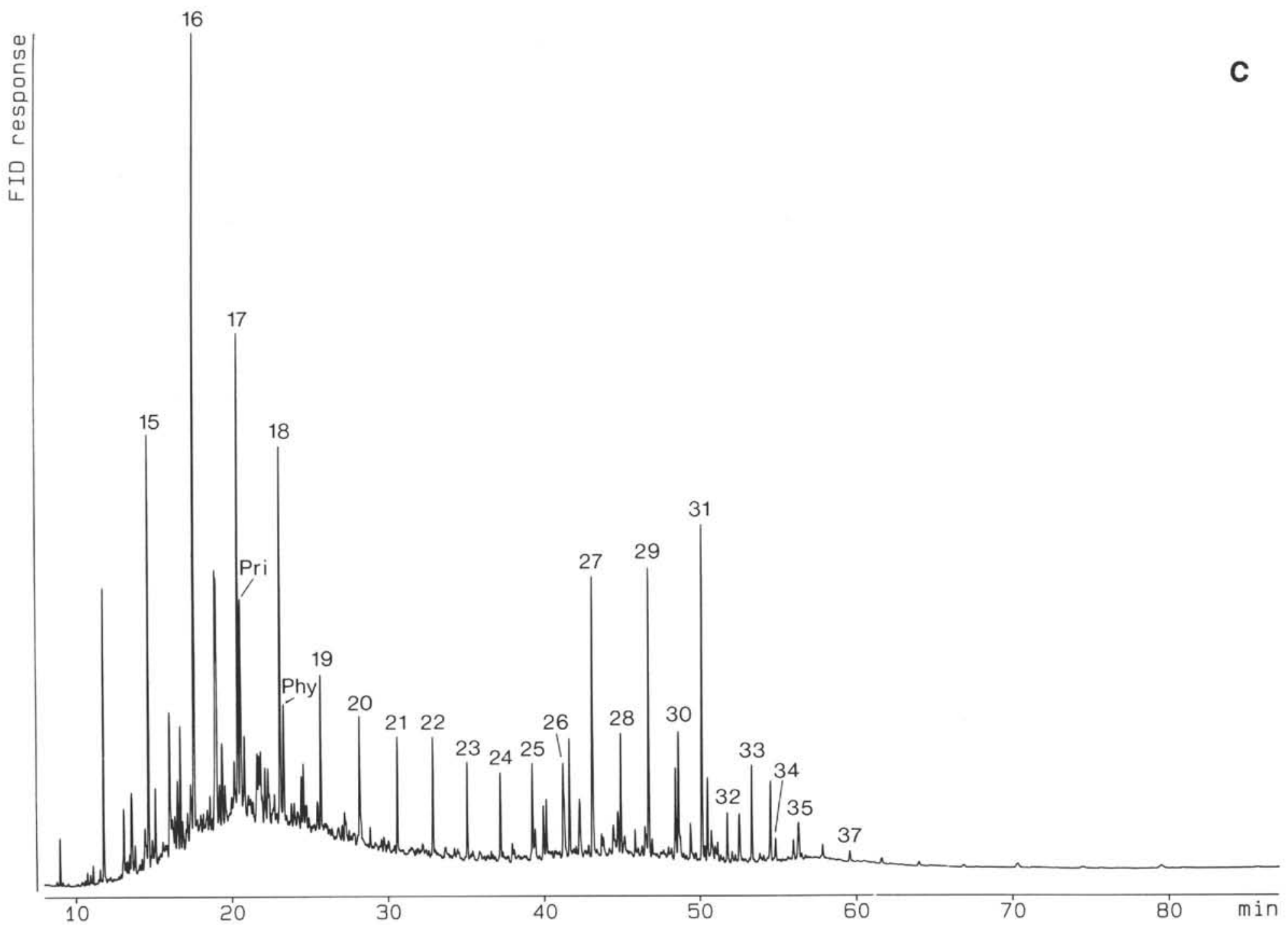

Figure 12 (continued). 
in favor of the more resistant terrigenous organic matter. Consequently, petrological and geochemical studies reveal that the bulk of the organic matter in all Leg 121 sedimentary units investigated is derived from terrestrial higher plants. Nevertheless, a subordinate proportion of organic matter derived from marine organisms is present particularly in sediments of Maestrichtian age at Site 754. We may speculate that most of this reached the sediment/water interface as fecal pellets which travel through the water column rapidly, to a certain extent unaffected by the oxygen present. The presence of hopanoids in the Santonian sediments at Site 755 and in the Campanian sediments at Site 758 indicates the preservation of bacterial biomass in these sequences. Dinoflagellates have probably contributed to the organic matter in the Campanian sediments at Site 758.

All hydrocarbon fractions investigated contain constituents that are characteristic of low levels of thermal stress. This is supported by low vitrinite reflectance values and a green-yellow fluorescence of sporomorphs and algae. The quantity of hydrocarbon gases also indicates a generally low level of maturation (Schaefer et al., this volume).

The small grain size of terrigenous organic particles (vitrinites and inertinites) reflects distal sources of organic matter for all stratigraphic units in all holes drilled on Broken Ridge and Ninetyeast Ridge. The grain-size distribution can be used as an indicator for the length of transport (Welte et al., 1979; ten Haven et al., 1990) because it mainly is a consequence of the mechanical breakdown of organic (wood) particles on their way from the site of plant growth to the site of deposition. The grain sizes of vitrinites and inertinites are less dependent on the size of precursor material than are the grain sizes of terrigenous minerals, which always reflect the mineralogy of the eroded rocks from which they are derived. In addition, terrigenous organic particles have more uniform densities and morphologies than do terrigenous minerals such as quartz or clay minerals.

In Cretaceous sediments on Broken Ridge (Site 755), terrigenous organic particles are much more abundant than in overlying Tertiary deposits, but the grain sizes are also small (Figs. 10 and 11). There is no sample displaying exceptionally large organic particles, neither in the Santonian nor in the Maestrichtian. This indicates a distant source of organic particles. According to Royer and Sandwell (1989), the Kerguelen-Heard Plateau was located only a few tens of kilometers south of Broken Ridge at that time. A transport over greater distances than a few tens of kilometers seems to provide a more likely explanation for the observed grain-size distribution so that sources in India or Australia can be assumed. This does not necessarily contradict the growth of plants on the Kerguelen-Heard Plateau at that time, but indicates a low probability for the direct transport of plant material from Kerguelen to Broken Ridge over short distances.

In the Campanian sediments recovered at Site 758 on the northern part of Ninetyeast Ridge, there are far fewer terrigenous organic particles of an average grain size even smaller than the particles in the Cretaceous sediments on Broken Ridge. This supports a source of the organic particles in the south or east of Broken Ridge. That is, it indicates that the terrigenous particles were derived from a southern continent (Australia) and transported by an oceanic surface-water current system running from southeast to northwest (Fig. 14). Whereas other explanations such as different sources for organic particles at Broken Ridge and Ninetyeast Ridge sites cannot be excluded, the data contradict a current system distributing organic particles from north to south through the Indian Ocean during the Late Cretaceous.

The high ratio of inertinites over vitrinites in the Santonian sediments at Site 755 compared to the Campanian and Maestrichtian sediments at Sites 758 and 754 is indicative of the deposition of more oxidized organic material at that time. This can easily be due to the fact that inertinites were not only transported by rivers and oceanic currents but in part also by wind (Welte et al., 1979, Rea et al., 1985). Winds will more probably transport inertinite precursors such as burned wood (charcoal) than vitrinite precursors (see Stach et al., 1982).

The positive correlation between organic matter accumulation and bulk sediment accumulation probably reflects the fact that nutrient supply and supply of terrestrial or volcanic material depend on the same factors and are therefore positively correlated. Also, an increasing supply of terrigenous organic particles may be expected for times of enhanced supply of terrestrial silicates. This factor may be responsible for the slightly elevated organic matter concentrations in the uppermost deposits at Site 758 which are influenced by the Bengal Fan, where the organic matter in the sediments is predominantly of terrigenous nature. It is, however, only of minor influence in the older sediments at Broken Ridge, where higher bulk sediment accumulation rates are due mainly to a higher input of volcanic material (Peirce, Weissel, et al., 1989; Rea et al., 1990). In accordance with this general finding, there is more marine alginite in the Maestrichtian (and Santonian) sediments on Broken Ridge than in the Neogene sediments at Site 758.

Furthermore, the exponential correlation between bulk sediment and organic carbon accumulation rates (i.e., the fact that a 10 -times-higher bulk sediment accumulation rate corresponds to a 100-times-higher organic carbon accumulation rate (Fig. $8 \mathrm{C}$ )) seems to indicate that not only did the supply of terrestrial organic particles and organic matter productivity increase, but that higher bulk sediment accumulation rates also led to a better preservation of (marine) organic particles at times of enhanced bulk sediment accumulation rates. Thus, an increase in bulk sediment accumulation rates generally seems to favor higher rates of organic carbon accumulation by (1) an increase in primary productivity due to higher nutrient availability, (2) a greater supply of terrigenous organic particles, and (3) better preservation, especially of the more labile organic matter synthesized by marine biota.

\section{ACKNOWLEDGMENTS}

The authors thank D. Müller for the microscopic evaluation of grain sizes of organic particles, M. Radke for supervision of extraction and liquid chromatography procedures, and W. Benders, E. Biermanns, U. Disko, A. Fischer, R. Harms, J. Höltkemeier, M. Juilfs, B. Kammer, F. J. Keller, and H. Schnitzler for various kinds of technical support. R. Littke wants to express his sincere gratitude to $\mathrm{D}$. H. Welte for the encouragement and permission to participate in the Leg 121 cruise. Financial and logistic support by the Deutsche Forschungsgemeinschaft (Grant No. We $346 / 27$ ) and the Bundesanstalt für Geowissenschaften und Rohstoffe is gratefully acknowledged.

\section{REFERENCES}

Calvert, S. E., 1974. Deposition and diagenesis of silica in marine sediments. In Hsü, K. J., and Jenkyns, H. C. (Eds.), Pelagic Sediments: On Land and Under the Sea. Spec. Publ. Int. Assoc. Sedimentol., 1:273-299.

Cook, A. C., 1974. Report on the petrography of a Paleocene brown coal sample from the Ninetyeast Ridge, Indian Ocean. In von der Borch, C. C., Sclater, J. G., et al., Init. Repts., DSDP, 22: Washington (U.S. Govt. Printing Office), 485-488.

Davies, T. A., Luyendyk, B. P., et al., 1974. Init. Repts., DSDP, 26: Washington (U.S. Govt. Printing Office).

Denton, G. H., and Armstrong, R. L., 1969. Miocene-Pliocene glaciations in southern Alaska. Am. J. Sci., 267:1121-1142.

Espitalié, J., Laporte, J. L., Leplat, P., Madec, M., Marquis, F., Paulet, J., and Boutefeu, A., 1977. Méthode rapide de caractérisation des roches mères, de leur potentiel pétrolier et de leur degrée d'évolution. Rev. Inst. Fr. Pet., 32:23-42.

Füchtbauer, H., 1988. Sedimente und Sedimentgesteine. Stuttgart (E. Schweizerbart'sche Verlagsbuchhandlung). 
Hunt, J. M., 1974. Hydrocarbon and kerogen studies. In von der Borch, C. C., Sclater, J. G., et al., Init. Repts., DSDP, 22: Washington (U.S. Govt. Printing Office), 673-676.

Katz, B. J., 1983. Limitations of "Rock-Eval" pyrolysis for typing organic matter. Org. Geochem., 4:195-199.

Kennett, J. P., 1982. Marine Geology: Englewood Cliffs, NJ (Prentice Hall).

Kennett, J. P., Houtz, R. E., Andrews, P. B., Edwards, A. E., Gostin, V. A., Hajos, M., Hampton, M., Jenkins, D. G., Margolis, S. V., Ovenshine, A. T., and Perch-Nielsen, K., 1975. Cenozoic paleoceanography in the southwest Pacific Ocean, Antarctic glaciation, and the development of the Circum-Antarctic Current. In Kennett, J. P., Houtz, R. E., et al., Init. Repts. DSDP, 29: Washington (U.S. Govt. Printing Office), $1155-1169$.

Leg 121 Scientific Party, 1988. Leg 121 traces rifting and hot spots. Geotimes, 33:9-11.

Leythaeuser, D., 1975. Erdölgenese in Abhängigkeit von der Art des organischen Materials im Muttergestein. Erdöl Kohle Erdgas Petrochem. Compendium, 74/75 (Suppl.):41-51.

Leythaeuser, D., Schaefer, R. G., and Radke, M., 1988. Geochemical effects of primary migration of petroleum in Kimmeridge source rocks from Brae field area, North Sea. I: gross composition of $\mathrm{C}_{15+-}$-soluble organic matter and molecular composition of $\mathrm{C}_{15+-}$-saturated hydrocarbons. Geochim. Cosmochim. Acta, 52:701-713.

Littke, R., Baker, D. R., and Leythaeuser, D., 1988. Microscopic and sedimentologic evidence for the generation and migration of hydrocarbons in Toarcian source rocks of different maturities. In Mattavelli, L., and Novelli, L. (Eds.), Advances in Organic Geochemistry 1987: Oxford (Pergamon Press), 549-559.

Luyendyk, B. P., and Davies, T. A., 1974. Results of DSDP Leg 26 and the geologic history of the Southern Indian Ocean. In Davies, T. A., Luyendyk, B. P., et al., Init. Repts. DSDP, 26: Washington (U.S. Govt. Printing Office), 909-943.

McKenzie, D. P., and Sclater, J. G., 1971. The evolution of the Indian Ocean since the late Cretaceous. Geophys. J. R. Astron. Soc., $25: 437-528$

Mienert, J., Stein, R., Schultheiss, P., and Shipboard Scientific Party, 1988. Relationship between grain density and biogenic opal in sediments from Sites 658 and 660 . In Ruddiman, W., Sarnthein, M., et al., Proc. ODP, Init. Repts., 108: College Station, TX (Ocean Drilling Program), 1047-1054.

Müller, P. J., and Suess, E., 1979. Productivity, sedimentation rate, and sedimentary organic matter in the oceans. I. Organic carbon preservation. Deep-Sea Res. Part A, 26:1347-1362.

Peirce, J., Weissel, J., et al., 1989. Proc. ODP, Init. Repts., 121: College Station, TX (Ocean Drilling Program).

Peirce, J., Weissel, J., Taylor, E., Dehn, J., Driscoll, N., Farrell, J., Fourtanier, E., Frey, F., Gamson, P. D., Gee, J. S., Gibson, I. L., Janecek, T., Klootwijk, C., Lawrence, J. R., Littke, R., Newman, J. S., Nomura, R., Owen, R. M., Pospichal, J. L., Rea, D. K., Resiwati, P., Saunders, A. D., Smit, J., Smith, G. M., Tamaki, K., Weis, D., and Wilkinson, C., 1988. A tale of two ridges. Nature, 335:593-594.

Peters, K. E., 1986. Guidelines for evaluating petroleum source rock using programmed pyrolysis. AAPG Bull., 70:318-329.

Pimm, A. C., 1974. Sedimentology and history of the Northeastern Indian Ocean from late Cretaceous to Recent. In von der Borch C. C., Sclater, J. G., et al., Init. Repts. DSDP, 22: Washington (U.S. Govt. Printing Office), 717-803.

Radke, M., Sittardt, H. G., and Welte, D. H., 1978. Removal of soluble organic matter from rock samples with a flow-through extraction cell. Anal. Chem., 50:663-665.

Radke, M., Willsch, H., and Welte, D. H., 1980. Preparative hydrocarbon group type determination by automated medium pressure liquid chromatography. Anal. Chem., 52:406-411.

Rea, D. K., Dehn, J., Driscoll, N., Farrell, J., Janecek, T., Owen, R. M., Pospichal, J. L., Resiwati, P., and the ODP Leg 121 Scientific Party,
1990. Paleoceanography of the Eastern Indian Ocean from ODP Leg 121 Drilling on Broken Ridge. Geol. Soc. Am. Bull., 102:679-690.

Rea, D. K., Leinen, M., and Janecek, T. R., 1985. Geologic approach to the long-term history of atmospheric circulation. Science, 227:721725 .

Robinson, N., Eglinton, G., Brassell, S. C., and Cranwell, P. A., 1984. Dinoflagellate origin for sedimentary $4 \alpha$-methylsteroids and $5 \beta(\mathrm{H})$ stanols. Nature, 308:439-441.

Royer, J. Y., and Sandwell, D. T., 1989. Evolution of the Eastern Indian Ocean since the Late Cretaceous: constraints from GEOSAT altimetry. J. Geophys. Res., 94:13524-13550.

Shipboard Scientific Party, 1989. Explanatory notes. In Peirce, J., Weissel, J., Proc. ODP, Init. Repts., 121: College Station, TX (Ocean Drilling Program), 33-62.

Simoneit, B. R., and Burlingame, A. L., 1974. Preliminary organic geochemical analyses of the Site 217 core samples in the Bengal Basin, DSDP Leg 22. In von der Borch, C. C., Sclater, J. G., et al., Init. Repts., DSDP, 22: Washington (U. S. Govt. Printing Office), 681-692.

Stach, E., Mackowsky, M.-Th., Teichmüller, M., Taylor, G. H., Chandra, D., and Teichmüller, R., 1982. Stach's Textbook of Coal Petrology (3rd ed.): Berlin (Gebrüder Borntraeger).

Stein, R., Littke, R., Stax, R., and Welte, D. H., 1989a. Quantity, provenance, and maturity of organic matter at ODP Sites 645, 646, and 647: implications for reconstruction of paleoenvironments in Baffin Bay and Labrador Sea during Tertiary and Quaternary time. In Srivastava, S. P., Arthur, M., Clement, B., et al., Proc. ODP, Sci. Results, 105: College Station, TX (Ocean Drilling Program), 185-208.

Stein, R., ten Haven, H. L., Littke, R., Rullkötter, J., and Welte, D. H., $1989 \mathrm{~b}$. Accumulation of marine and terrigenous organic carbon at upwelling Site 658 and nonupwelling Sites 657 and 659: implications for the reconstruction of paleoenvironments in the eastern subtropical Atlantic through late Cenozoic times. In Ruddiman, W., Sarnthein, M., et al., Proc. ODP, Sci. Results, 108: College Station, TX (Ocean Drilling Program), 361-385.

Stein, R., Rullkötter, J., Littke, R., Schaefer, R. G., and Welte, D. H., 1988. Organofacies reconstruction and lipid geochemistry of sediments from the Galicia Margin, Northeast Atlantic (ODP Leg 103). In Boillot, G., Winterer, E. L., et al., Proc. ODP, Sci. Results, 103: College Station, TX (Ocean Drilling Program), 567-585.

Styan, W. B., and Bustin, R. M., 1983. Petrography of some Fraser river delta peat deposits: coal maceral and microlithotype precursors in temperate-climate peats. Int. J. Coal Geol., 2:321-370.

Teichmüller, M., 1982. Origin of the petrographic constituents of coal. In Stach, E., Mackowsky, M.Th., Teichmüller, M., Taylor, G. H., Chandra, D., and Teichmüller R. (Eds.), Stach's Textbook of Coal Petrology: Berlin (Bornträger-Verlag), 219-294.

ten Haven, H. L., Littke, R., Rullkötter, J., Stein, R., and Welte, D. H., 1990. Accumulation rates and composition of organic matter in late Cenozoic sediments underlying the active upwelling area off Peru. In Suess, E., von Huene, R., et al., Proc. ODP, Sci. Results, 112: College Station, TX (Ocean Drilling Program), 591-606.

Tissot, B. P., and Welte, D. H., 1984. Petroleum Formation and Occurrence (2nd ed.): Heidelberg (Springer-Verlag).

van Andel, T. H., 1975. Mesozoic/Cenozoic calcite compensation depth and the global distribution of calcareous sediments. Earth Planet. Sci. Lett., 26:187-194.

von der Borch, C. C., Sclater, J. G., et al., 1974. Init. Repts. DSDP, 22: Washington (U.S. Govt. Printing Office).

Welte, D. H., Cornford, C., and Rullkötter, J., 1979. Hydrocarbon source rocks in deep sea sediments. 11th Ann. Offshore Technol.Conf., Proc., $457-461$.

Date of initial receipt: 14 February 1990

Date of acceptance: 1 August 1990

Ms 121B-129 
Table 3. Biological markers identified in the saturated hydrocarbon fractions of Leg 121 samples (see Fig. 13A-C).

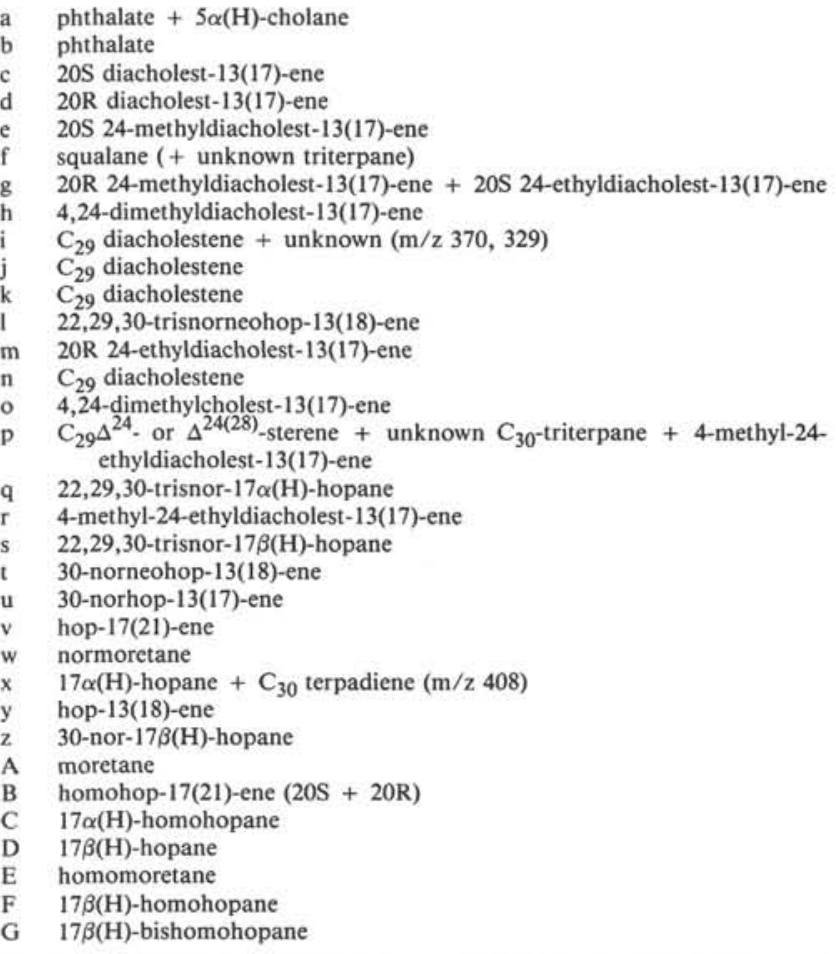

phthalate

20 S diacholest-13(17)-ene

20R 24-methyldiacholest-13(17)-ene $+20 \mathrm{~S}$ 24-ethyldiacholest-13(17)-ene

ethyldiacholest-13

29 diacholesten

22,29,30-trisnorneohop-13(18)-ene

20R 24-ethyldiacholest-13(17)-ene

$\mathrm{C}_{29} \Delta^{24}$. or $\Delta^{24(28)}$-sterene + unknown $\mathrm{C}_{30}$-triterpane + 4-methyl-24ethyldiacholest-13(17)-en

(13)-ene

$7 \alpha(\mathrm{H})$-hopane $+\mathrm{C}_{30}$ terpadiene $(\mathrm{m} / \mathrm{z} 408)$

hop-13(18)-ene

homohop-17(21)-ene $(20 \mathrm{~S}+20 \mathrm{R})$

$17 \alpha(\mathrm{H})$-homohopane

$17 \beta(\mathrm{H})$-bishomohopane

Table 4. Summary of carbon preference index (25-31) values and isoprenoid hydrocarbon concentration ratios.

\begin{tabular}{|c|c|c|c|}
\hline Sample & $\begin{array}{c}\text { Carbon } \\
\text { preference } \\
\text { index }(25-31)\end{array}$ & Pristane $/ n-\mathrm{C}_{17} \mathrm{H}_{36}$ & Pristane/Phytane \\
\hline 121-754B-15R-5, 38-41 & 1.92 & 0.68 & 1.56 \\
\hline $121-754 \mathrm{~B}-24 \mathrm{R}-2,24-29$ & 3.64 & 0.72 & 1.97 \\
\hline $121-754 \mathrm{~B}-25 \mathrm{R}-1,44-46$ & 2.27 & 0.81 & 1.72 \\
\hline $121-755 \mathrm{~A}-13 \mathrm{R}-1,93-96$ & 1.69 & 0.89 & 2.13 \\
\hline $121-755 \mathrm{~A}-14 \mathrm{R}-4,12-15$ & 2.18 & 0.67 & 1.92 \\
\hline $121-755 \mathrm{~A}-16 \mathrm{R}-2,95-98$ & 1.77 & 0.74 & 1.76 \\
\hline $121-755 \mathrm{~A}-19 \mathrm{R}-4,63-66$ & 1.49 & 0.66 & 1.70 \\
\hline $121-758 \mathrm{~A}-1 \mathrm{H}-2,105-108$ & 2.92 & 0.66 & 1.81 \\
\hline $121-758 \mathrm{~A}-3 \mathrm{H}-2,95-98$ & 3.06 & 0.73 & 1.85 \\
\hline $121-758 \mathrm{~A}-56 \mathrm{R}-2,80-83$ & 2.82 & 0.64 & 1.81 \\
\hline
\end{tabular}




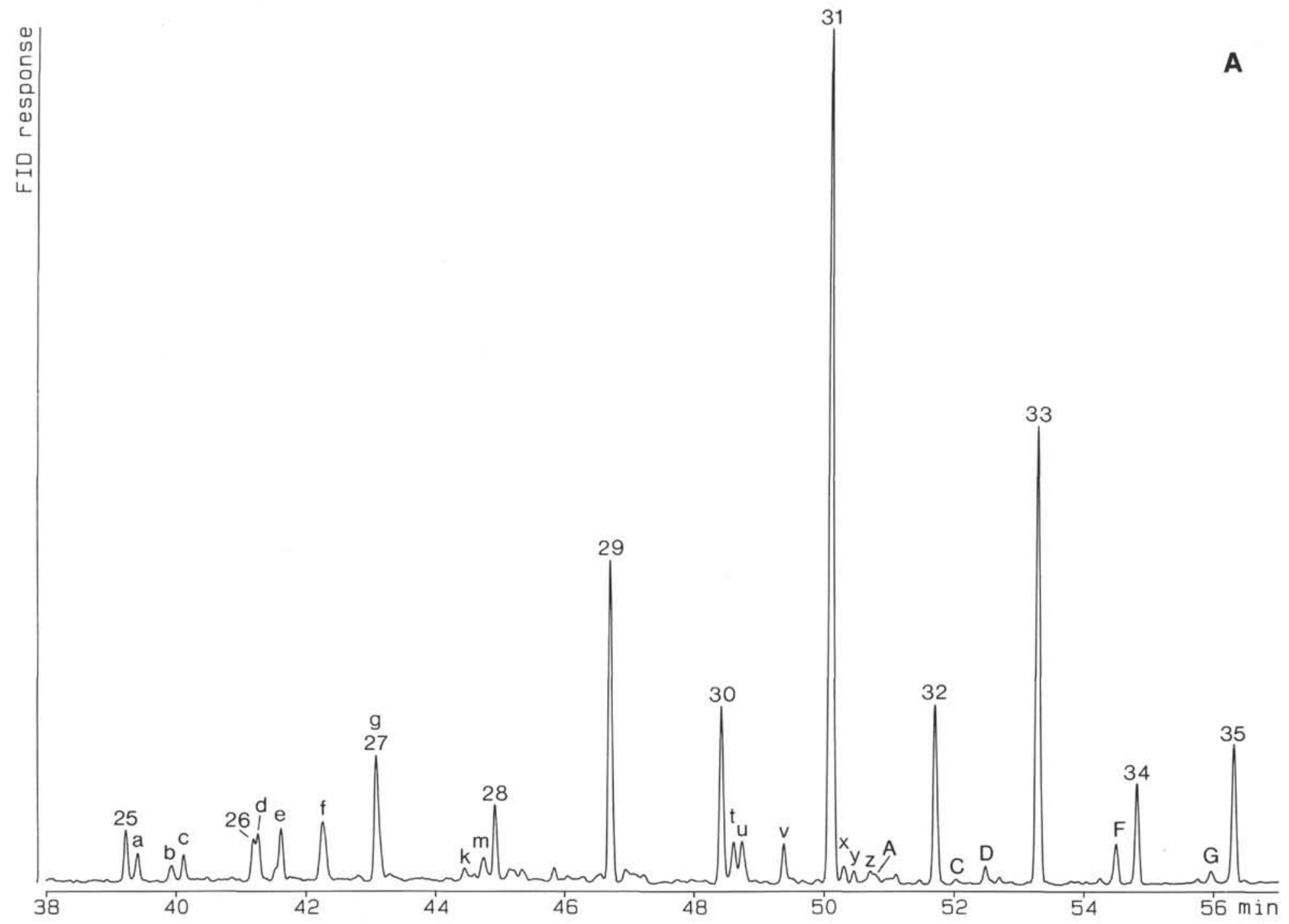




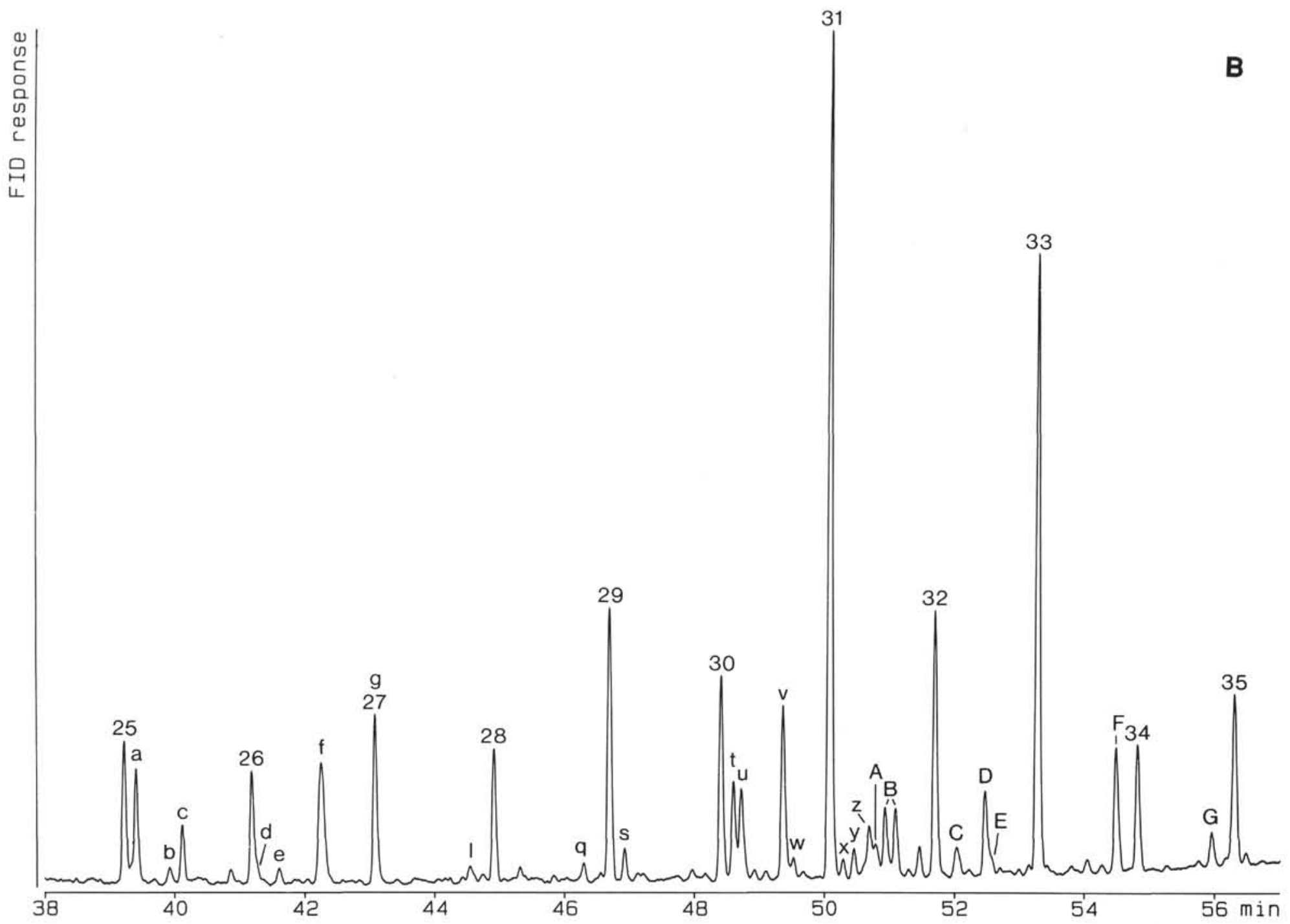

Figure 13. Partial gas chromatograms of the saturated hydrocarbon fraction of the same selected samples from Sites 754,755 , and 758 as depicted in Figure 12 (see Table 3 for identification of peaks marked with letters; numbers indicate $n$-alkanes). (Note: FID = flame ionization detector.) 


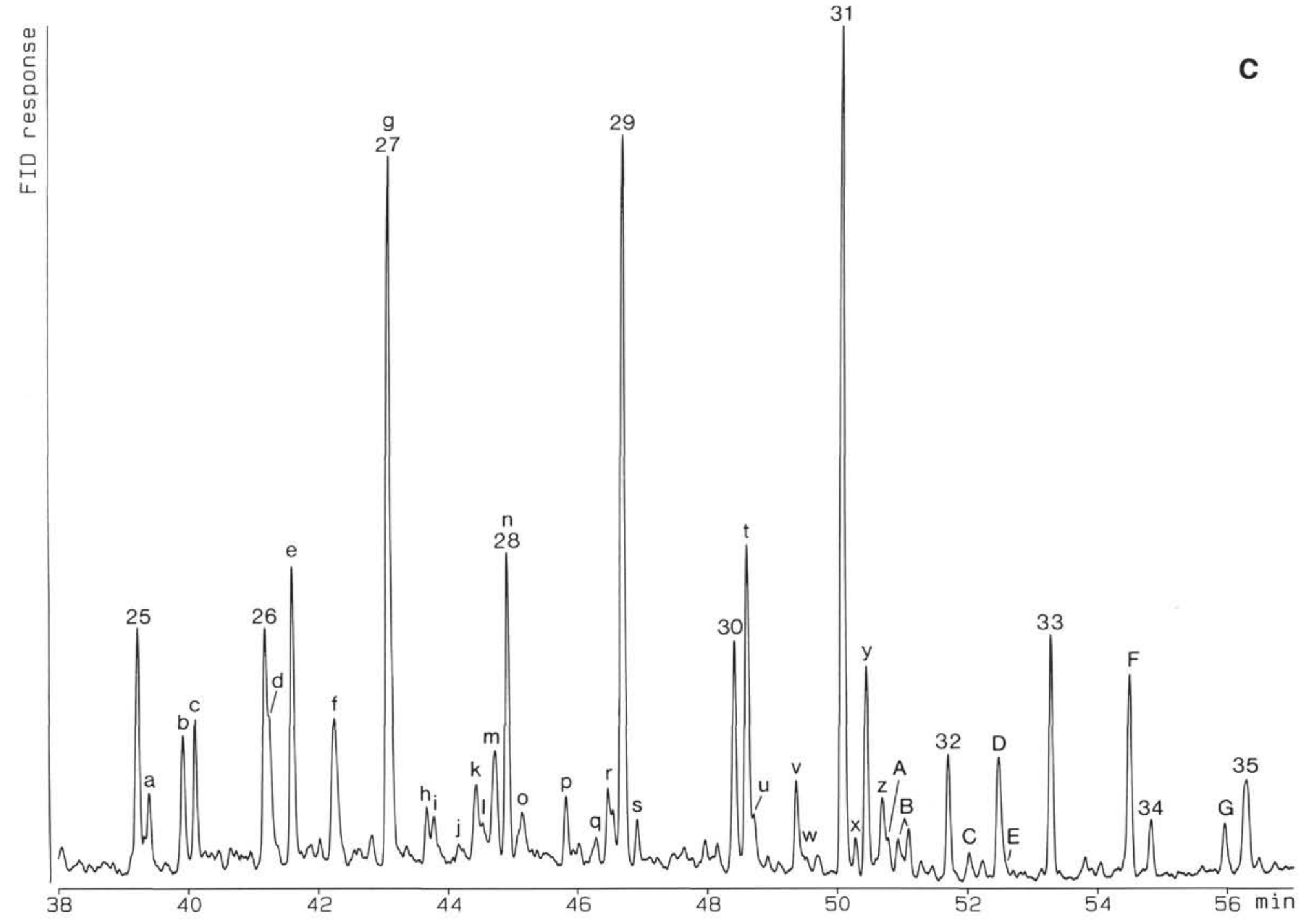

Figure 13 (continued). 


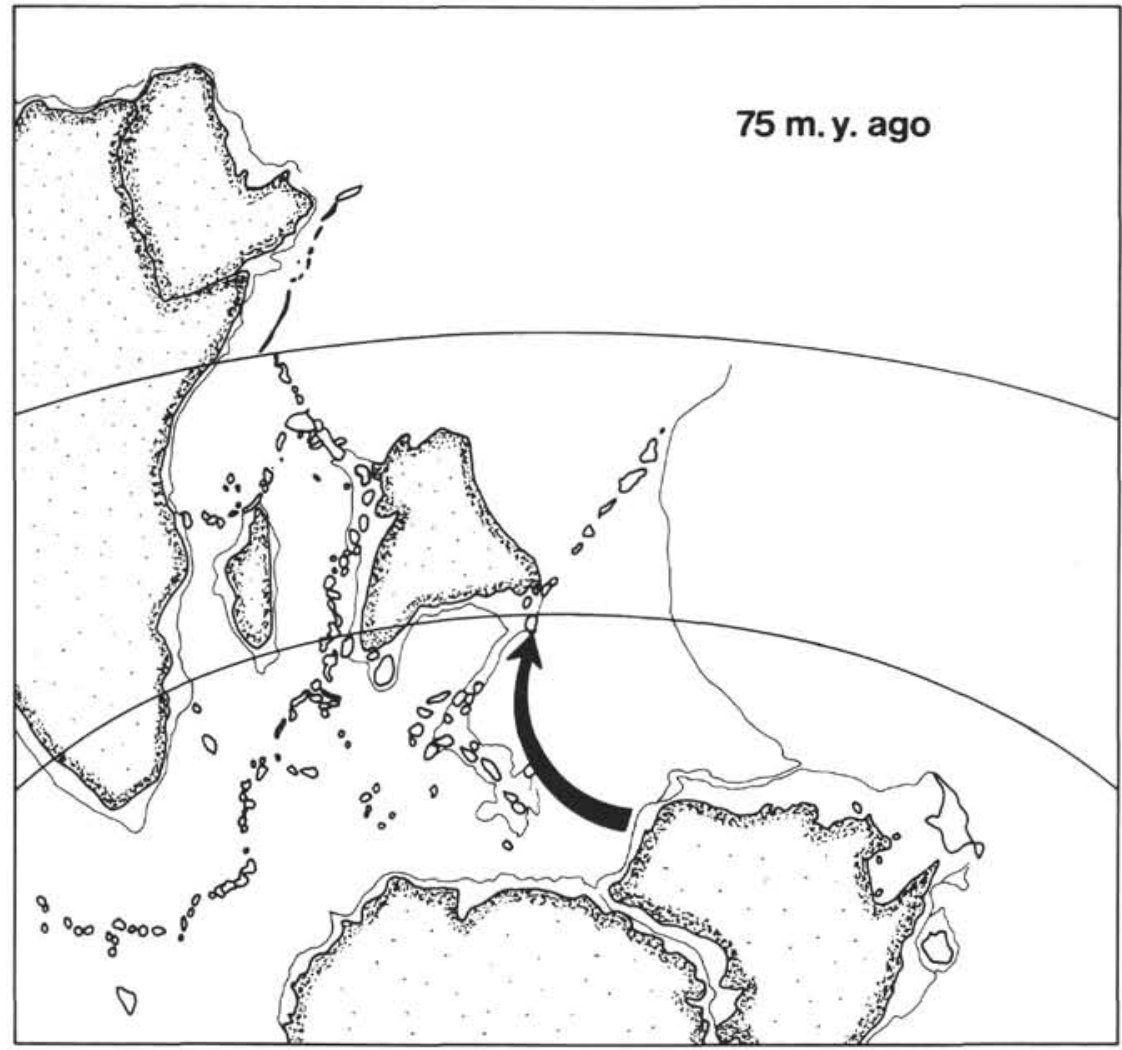

Figure 14. Proposed surface water paleocurrent (arrow) prevailing during Upper Cretaceous times in the Proto-Indian Ocean. A north-south-directed current seems to be unlikely according to the number and average grain size of terrigenous organic particles. The 75-m.y.-ago reconstruction is modified after McKenzie and Sclater (1971) and von der Borch, Sclater, et al. (1974). 